http://kitaibelia.unideb.hu/

ISSN 2064-4507 (Online) • ISSN 1219-9672 (Print)

(C) 2017, Department of Botany, University of Debrecen, Hungary

22 (1): 122-146.; 2017

DOI: $10.17542 /$ kit.22.122

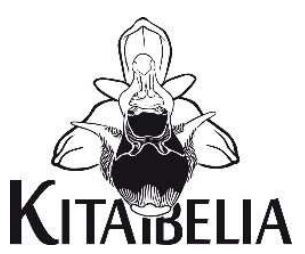

\title{
Pótlások Magyarország edényes növényfajainak elterjedési atlaszához III.
}

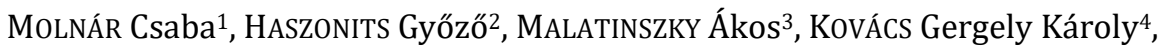 \\ KovÁcs Gábor ${ }^{5}$ NAGY Timea6, MolnÁR V. Attila7 \& TAKÁcs Attila7 \\ (1) H-3728 Gömörszőlős, Kassai u. 34. \\ (2) H-9165 Rábcakapi, Gátőrház \\ (3) Szent István Egyetem MKK Természetvédelmi és Tájgazdálkodási Intézet, \\ Természetvédelmi és Tájökológiai Tanszék, H-2103 Gödöllő, Páter K. u. 1. \\ (4) „VÖLGY-HÍD” Természetvédelmi Alapítvány H-8092 Pátka hrsz. 2606/3. \\ (5) H-4071 Hortobágy, Czinege János u. 12. \\ (6) Pannon Egyetem GK Növénytudományi és Biotechnológiai Tanszék, H-8360 Keszthely, Festetics u. 7. \\ (7) Debreceni Egyetem TTK Növénytani Tanszék, H-4032 Debrecen, Egyetem tér 1.
}

\section{Contributions to the Atlas Florae Hungariae III.}

\begin{abstract}
The current paper is the third one in the series aiming to contribute with new distribution data to the distribution maps published recently in Atlas Florae Hungariae. Current occurrence data of 558 vascular plant taxa from 186 flora mapping quadrates (CEU) are presented. New records are indicated from different regions of Hungary; however, most occurrences are located in the North Hungarian Mts. Occurrence data of rare native taxa (e.g. Marsilea quadrifolia, Salicornia prostrata, Stellaria palustris, Potentilla patula, Althaea cannabina, Lythrum tribracteatum, Ajuga laxmannii, Plantago schwarzenbergiana, Alisma gramineum, Gagea bohemica, G. szovitsii), rare or data-deficient alien taxa (e.g. Chorispora tenella, Thladiantha dubia, Senecio vernalis) as well as frequent but more or less underrepresented taxa (e.g. Scleranthus annuus, Vicia hirsuta, V. lathyroides) are also enumerated. In case of the most common species we provided the CEU codes only.
\end{abstract}

Keywords: distribution data, flora mapping, flora of Hungary, vascular flora

Összefoglalás - Jelen közleményünk annak a sorozatnak a harmadik része, melynek célja a Magyarország edényes növényfajainak elterjedési atlasza térképeinek kiegészítése, fóként aktuális előfordulási adatokkal. Ezúttal 558 edényes taxon előfordulási adatait közöljük az ország szinte egész területéről (mintegy 186 flóratérképezési kvadrátból), de legnagyobb számban az Északiközéphegységből. Az adatok között ritkább őshonos taxonok (például Marsilea quadrifolia, Salicornia prostrata, Stellaria palustris, Potentilla patula, Althaea cannabina, Lythrum tribracteatum, Ajuga laxmannii, Plantago schwarzenbergiana, Alisma gramineum, Gagea bohemica, G. szovitsii), ritka, vagy legalábbis adathiányos idegenhonos fajok (például Chorispora tenella, Thladiantha dubia, Senecio vernalis) mellett országosan elterjedt, de többé-kevésbé alulreprezentált fajok (például Scleranthus annuus, Vicia hirsuta, V. lathyroides) esetében is közöljük az Atlasz térképeihez képest újnak bizonyuló lelőhelyeket. A legközönségesebb fajok esetében a lelőhelyek részletezése nélkül csupán KEF-kódokat adunk meg.

Kulcsszavak: edényes flóra, elterjedési adatok, flóratérképezés, Magyarország flórája 


\section{Bevezetés}

Közleményünk a Magyarország edényes növényfajainak elterjedési atlasza (BARTHA et al. 2015) térképeinek kiegészítésére hivatott sorozat (TAKÁcs et al. 2016, MoLNÁR et al. 2016) harmadik része. Ezúttal összesen 558 edényes taxon aktuális előfordulási adatait közöljük, köztük, korábbi közleményeinkhez hasonlóan néhány olyan taxonét is, amelyekről a flóraatlasz nem (például Eichhornia crassipes), vagy csupán fajcsoportba összevonva közöl elterjedési adatokat (például Chamaecytisus triflorus). Adataink 186 flóratérképezési kvadrátból származnak, amelyek elsősorban az Északi-középhegység területét reprezentálják (1. ábra). Az adatok szórvány jellegét jelzi, hogy 154 kvadrátból csupán 1-10 adatot közlünk, míg 30nál többet csak 6 esetben (1. ábra), jellemzően olyan területekről, ahová az utóbbi években a szerzők terepmunkája összpontosult. Az adatok egy része a flóratérképezés során a szerzők által felmért kvadrátok flóralistáját egészíti ki, a kitöltött adatlapok leadása utáni terepmunkák eredményeként. Az adatok jórészt 2000-2017 között keletkeztek, csupán 6 adat származik az ezredforduló előtti időszakból. A lelőhelyeket követően a közép-európai flóratérképezés kvadrátjainak azonosítói (NIKLFELD 1971) mellett feltüntetjük az adat gyưjtésének évét, valamint az adatközlők értelemszerű monogramjait (vö. szerzők). A taxonok sorszámozása KIRÁLY (2009) munkáját követi.

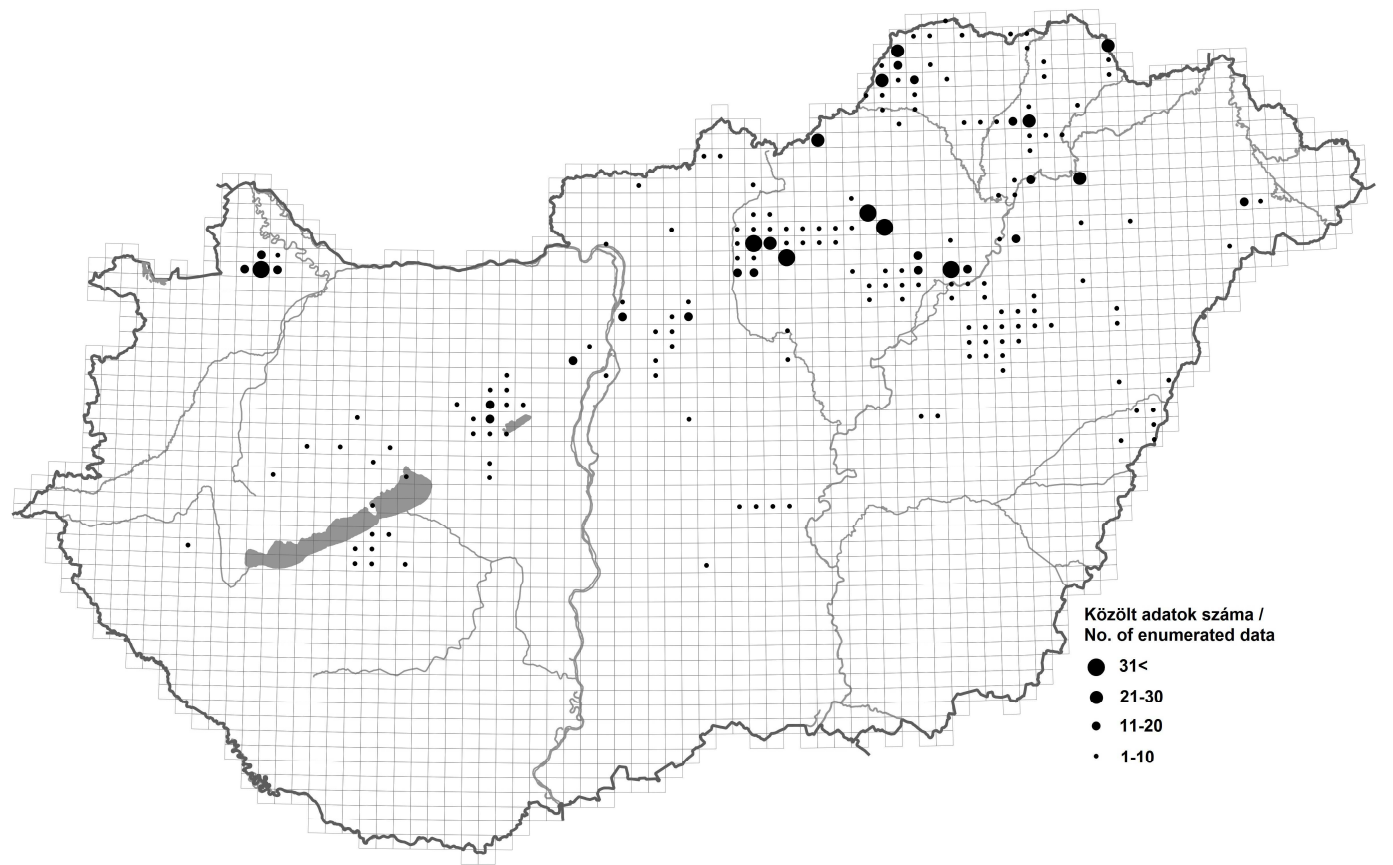

1. ábra. A közleményben összefoglalt előfordulási adatok a közép-európai flóratérképezés (KEF) hálórendszerének kvadrátjaira vetítve

Fig. 1. Distribution of localities of presented data, in projection of quadrates of the Central Europaean flora mapping system (CEU)

Az Enumerációban felsorolt adataink közül kiemelnénk például az országosan ritka Ophioglossum vulgatum, Stellaria palustris, Chorispora tenella, Potentilla patula, Euphorbia peplus, Althaea cannabina, Taraxacum bessarabicum és T. palustre előfordulási adatait, az Alföldön ritkaságnak számító Asplenium trichomanes és Adonis vernalis adatait. Alföldi elter- 
jedésük északi pereméről kerőltek elő a Lythrum tribracteatum, Plantago schwarzenbergiana és a Ventenata dubia újabb lelőhelyei, míg ismet hazai elterjedési területükön belül, de újabb kvadrátokból jelezzük például az Alisma gramineum, Salicornia prostrata, Heliotropium supinum, Marsilea quadrifolia, Lycopsis arvensis, Leucanthemella serotina, Gagea bohemica, Gagea szovitsii és az Ajuga laxmannii adatait.

Az említett, florisztikai, növényfoldrajzi illetve természetvédelmi szempontból érdekes előfordulási adatok mellett szórványos vagy gyakori taxonok előfordulásit is közöljük, köztük kultivált fajokét is (például Juglans nigra, Syringa vulgaris, Brassica ×napus stb.). Utóbbiak adatai kivétel nélkül spontán vagy szubspontán állományokat jeleznek.

\section{Enumeráció}

13.Equisetum palustre L. - Lébény: Polgári Pintér-Hany láprétjeinek mélyebb fekvésű részein fordul elő szórványosan [8269.4, 2016, HGy].

14.Equisetum ramosissimum Desf. - Lébény: 8528-as számú közút mentén elhelyezkedő Farkas-domb K-i oldalán található kis 10-15 tövet számláló állománya [8270.3, 2016, HGy]. 17. Ophioglossum vulgatum L. - Tiszalök: Lökös-dűlő [7994.4, 2014, MCs]. Tiszadorogma: Keszeges és Nagy-vájás között, mocsárréten [8291.3, 2014, MCs].

37.Asplenium trichomanes L. - Püspökladány: Hatoséri-kút, kútaknában [8692.1, 2015, KG]. Nádudvar: Kösely-torkolat [8692.1, 2006, KG].

43. Cystopteris fragilis (L.) Bernh. - [7595.2, 2011, MCs].

60. Marsilea quadrifolia L. - Hortobágy: Kondás [8392.2, 2010, KG].

98. Salix rosmarinifolia L. - Lébény: Polgári-Pintér Hany, Fűzfaszigetek, láp-mocsárréteken gyakori [8269.4, 8269.2, 8270.1, 2015, HGy]. Székesfehérvár: Borszéki úti láprét [8876.1, 2016, KGK]. Újrónafö: Krisztina-berek [8269.2, 2014, HGy].

99.Salix purpurea L. - Nagycsepely: a halastó közelében [9272.4, 2016, NT].

110. Juglans regia L. - [7788.2, 2013, MCs].

111. Juglans nigra L. - Zádorfalva: Nagy-Szőlő-tető [7588.4, 2014, MCs].

134. Ulmus minor Mill. - [8284.3, 2009, MÁ].

139. Morus alba L.- [8284.3, 2009, MÁ]. [7793.3, 2014, MCs].

146. Urtica urens L.- Szalmatercs: Cseres-oldal [7883.4, 2011, MÁ].

153. Thesium linophyllon L. - Domaháza: Bikk [7886.2, 2013, MCs].

155. Loranthus europaeus Jacq. - Kisnána: Macskavár [8186.4, 2007, MCs].

157. Asarum europaeum L. - Szólád: Nezde [9273.1, 2016, NT].

162. Persicaria maculosa S.F.Gray - Nyírcsaholy: Lebuc-dűlő [8000.3, 2014, MCs].

164. Persicaria hydropiper (L.) Delarbre - Bátorliget: Cserepesi-legelő [8299.1, 2014, MCs].

165. Persicaria dubia (Stein) Fourr. - Felsőtárkány: Tiba alja [8088.3, 2010, MCs]. Novaj: Gyűr-oldal, telepített tölgyesben [8188.2, 2010, MCs]. Tiszabábolna: Orosz-ér és Tiszavalkifőcsatorna között [8290.4, 2014, MCs].

166. Persicaria minor (Huds.) Opiz - Gyöngyöspata: Havas, vizes keréknyomban [8184.4, 2008, MCs]. Novaj: Herman-tető, fiatal szőlőparlagon [8188.2, 2010, MCs].

172. Polygonum aviculare L. s. str. - [7886.2, 2013, MCs].

178. Fallopia dumetorum (L.) Holub - Abasár: Rónya-bérc [8186.3, 2013, MCs]. Apc: Tarcodhegy és Gyöngyöspata: Csárda-puszta erdeje és Antal-hegy [8184.3, 2007, MCs]. Aszaló: Paperdő [7791.4, 2012, MCs]. Domony: Faház-tető és Gödöllő: Látó-hegy [8382.4, 2006, MCs]. Dubicsány: Gyöngyös-hegy [7788.2, 2013, MCs]. Feldebrő: Cser [8187.3, 2007, MCs]. Felsőtárkány: Ostoros-völgy [8088.3, 2010, MCs]. Gödöllő: Pulyka-tető [8482.1, 2006, MCs]. Gödöllő és Valkó: az erdőben sokfelé [8482.2, 2006, MCs]. Gömörszőlős: Hideg-völgy [7688.2, 2013, MCs]. Gyöngyös: Sár-hegy [8285.2, 2010, MCs]. Gyöngyöspata: János vára és Gyöngyöstarján: Káva [8184.2, 2006, MCs]. Gyöngyöspata-Gyöngyöstarján: Havas [8184.4, 
2008, MCs]. Gyöngyössolymos: A Csór-réti tározó és a Hidasi-erdészház közötti villanyvezeték-vízvezeték nyomvonalán [8185.2, 2004, MCs]. Gyöngyöstarján: a falu feletti erdőkben [8185.1, 8185.3, 2006, MCs]. Hernádpetri: Agyagos-oldal feletti erdőkben [7593.1, 2006, MCs]. Kisnána: Hosszú-hegy lába [8186.2, 2007, MCs]. Kisújszállás: Nagy-erdő [8790.3, 2006, MCs]. Mátraszentimre: Óvár és Pásztó-Hasznos: Gombás-oldal [8084.4, 2006, MCs]. Parád: Som-hegy és Marhád [8186.1, 2006, MCs]. Pásztó: Kerek-domb [8184.1, 2007, MCs]. Pécel: Vár-hegy [8482.3, 8582.1, 2006, MCs]. Sajóvámos: Rednek-erdő, a Frank-hegy csúcsa mellett [7791.3, 2012, MCs]. Szuha-Mátraalmás: Galyavár [8085.3, 2006, MCs].

179. Fallopia convolvolus (L.) Á.Löve - [8284.3, 2009, MÁ]. [7489.4, 7490.3, 2007, MCs].

185. Rumex acetosella L. - [8099.4, 2014, MCs]. [7689.2, 2013, MCs]. [7695.2, 2007, MCs].

187. Rumex acetosa L. - [8184.4, 2008, MCs]. [8185.4, 2007, MCs].

198. Rumex conglomeraus Murray - Valkó: Erzsébet-pihenő mellett [8482.2, 2006, MCs].

201. Rumex stenophyllus Ledeb. - Felsőtárkány: Tiba alja-dűlő [8088.3, 2010, MCs].

202. Rumex crispus L. - [8184.4, 2010, MCs]. [8088.3, 2010, MCs]. [8185.3, 2010, MCs]. [8188.2, 2010, MCs]. [7793.3, 2008, MCs]. [8579.3, 2011, MCs]. [7688.2, 2013, MCs].

203. Rumex patientia L. - [8284.4, 2011, MCs]. [8790.3, 2006, MCs]. [7793.3, 2008, MCs]. [8579.3, 2011, MCs].

207. Polycnemum arvense L. - Gyöngyös-Visonta: Cseplye-tető és Visontai-hegy [8285.2, 2010, MCs].

216. Chenopodium bonus-henricus L. - Pénzesgyőr: fás legelő Hárskút felé [8772.4, 2006, MÁ].

221. Chenopodium polyspermum L. - Alsószuha: Rónya-puszta, napraforgótábla [7689.1, 2010, MÁ]. Feldebrő: Cser, völgyalji, üde erdő [8187.3, 2007, MCs].

222. Chenopodium hybridum L. - [8187.3, 2007, MCs].

223. Chenopodium murale L. - Abaújszántó: belterület, kőfal mentén [7793.1, 2016, MCs].

237. Atriplex prostrata Boucher - Hatvan: kisgombosi fás legelő [8284.3, 2009, MÁ].

250. Salicornia prostrata Pall. - Nagyiván: Sároséri-főcsatorna [8591.2, 2016, KG]. Székesfehérvár: Gödör utcai, téglagyári kubikban kialakuló másodlagos szikes [8776.4, 2011, KGK].

262. Amaranthus powellii S.Watson - [7688.2, 2016, MCs].

273. Phytolacca americana L. - Sajóivánka: Bikk, bükkösben [7789.3, 2014, MCs].

280. Arenaria procera Spreng. - Bátorliget: Bátori- és Cserepesi-legelő [8299.1, 2014, MCs]. Nyírcsaholy: Szentmiklósi-dűlő, lovasudvar [8099.4, 2014, MCs].

281. Arenaria serpyllifolia L. s. str. - [8087.2, 2007, MCs].

283. Moehringia trinervia (L.) Clairv. - Gyöngyöspata: Havas [8184.4, 2008, MCs].

295. Stellaria holostea L. - Gödöllő: Pulyka-tető [8482.1, 8482.2, 2006, MCs].

297. Stellaria graminea L. - Gyöngyössolymos: Tarma-oldal [8185.4, 2007, MCs]. Lébény: Tárnokréti közelében fekvő félszáraz legelő, bormászpusztai úttól NY-ra [8269.4, 2016, HGy].

298. Stellaria palustris Retz. - Lébény: a Polgári-Pintér Hanyban találtam 10-15 tövet számláló állományát, a terület egy magassásos láprét; a Laci rétektől ÉNY-ra helyezkedik el [8269.4, 2016, HGy].

299. Holosteum umbellatum L. - [8196.1, 2011, MCs].

300. Cerastium dubium (Bastard) Guépin - Egerlövő: Tilaj és Mezőkövesd, Kánya-patak menti gyepekben [8289.4, 2014, MCs]. Kesznyéten: Szamár-háttól D-re, vetett gyepben [8092.1, 2014, MCs]. Rábcakapi: üde legelőkön, kaszálóréteken ritka [8269.4, 2015, HGy]. Tiszadob: Ó-Kenéz [7993.3, 2014, MCs] és Horgoló [8092.2, 2014, MCs]. Tiszalök: Lökösdűlő [7994.4, 2014, MCs].

301. Cerastium glomeratum Thuill. - Kisnána: Macskavár [8186.4, 2007, MCs]. Rábcakapi: töltéspartok délies meleg oldalai [8269.4, 2016, HGy].

302. Cerastium tenoreanum Ser. - Rábcakapi: délies kitettségű száraz töltésoldalakban szórványos [8269.4, 2016, HGy]. 
303. Cerastium brachypetalum Desp. - Lébény: Nagy-dombon találtam kisebb állományait [8270.1, 2016, HGy].

305. Cerastium semidecandrum L. - Bátorliget: Bátori- és Cserepesi-legelő [8299.1, 2014, MCs]. Budapest: M3 Szilas pihenőhely [8480.2, 2011, MCs]. Nyírcsaholy: Szentmiklósi-dűlő, lovasudvar [8099.4, 2014, MCs].

306. Cerastium pumilum Curtis - Mikóháza: Nagy-Polyán, legelőn [7595.2, 2009, MCs]. Mikóháza: Kis-Polyán, legelőn [7595.4, 2009, MCs].

307. Cerastium glutinosum Fr. s. str. - Aggtelek: Kardos-völgy, csarabosban [7589.3, 2013, MCs].

310. Cerastium lucorum (Schur) Möschl - Gyöngyöspata: Ferge-rét [8184.4, 2008, MCs].

311.1. Cerastium arvense L. s. str. - Szuhogy: Bilice-oldal, parlagon [7689.2, 2013, MCs].

323. Scleranthus annuus L. - Eger-Szarvaskő: Vár sánca melletti kis tisztáson [8087.2, 2007, MCs]. Novaj: a belterülettől É-ra, erózió miatt felszínre került riolittufán [8188.2, 2010, MCs]. Tihany: Gödrös, Diósi-rétek fölött, kis pihenőnél és Szélmarta sziklák alatt [9073.3, 2007, MCs]. Szentistván: Salamon-major mellett [8290.4, 2014, MCs].

334. Lychnis flos-cuculi L. - Hortobágy: Árpádhalom [8493.1, 2016, KG]. Nyírcsaholy: Lebucdűlő [8000.3, 2014, MCs]. Pátka: Zámolyi-víztározó túlfolyója [8676.4, 2016, KGK].

335. Lychnis coronaria (L.) Desr. - Budapest: Széchenyi-hegy [8579.2, 2015, MÁ].

336. Lychnis viscaria L. - Nagycsepely: ótemető [9273.3, 2016, NT]. Novaj: Pipis-tető D-i oldala, egykori riolittufa-bányában [8188.2, 2010, MCs].

337. Agrostemma githago L. - Hortobágy: Csécs-3 etetőtorony alatt [8492.3, 2016, KG] és Akadémia 3-4 etetőtorony alatt [8492.1, 2016, KG]. Újlengyel: búzavetés [8782.4, 2013, KGK]. Pátka: Páskom, kisparcellák, több helyen [8776.2, 2016, KGK]. Székesfehérvár: Pénzverő-völgy biotábla szegélye, [8776.4, 2014, KGK]. Vértesacsa: temető melletti szántóföld [8677.1, 2016, KGK].

338. Silene vulgaris (Moench) Garcke - [8188.2, 2010, MCs].

343. Silene conica L. - Domaháza: Cé-lápa mellett, homokos parlagon [7886.2, 2013, MCs].

351. Silene nemoralis Waldst. et Kit. - Aggtelek: Kardos-völgy, csarabosban [7589.3, 2013, MCs]. Dubicsány: Gyöngyös-hegy [7788.2, 2013, MCs].

352. Silene noctiflora L. - Gyöngyössolymos: A Csór-réti tározó és a Hidasi-erdészház közötti villanyvezeték-vízvezeték nyomvonalán [8185.2, 2004, MCs].

353. Silene nutans L. - Gödöllő: Pulyka-tető [8482.1, 2006, MCs] és Juharos-bérc [8482.2, 2006, MCs]. Kereki: temető melletti gyep [9173.4, 2016, NT]. Nagycsepely: ótemető [9273.3, 2016, NT]. Tarnaszentmária: Vár-hegy [8187.1, 2005, MCs]. Tállya: Patócs-hegy [7793.3, 2008, MCs]. Teleki: Templom-dűlő [9272.2, 2016, NT].

355. Cucubalus baccifera L. - Valkó: Erzsébet-pihenő és környéke [8482.2, 2006, MCs]. Visonta: Bajna-dülő [8285.2, 2010, MCs].

356. Gypsophila muralis L. - [8088.3, 2010, MCs].

370. Dianthus deltoides L. - Eger-Felnémet: Ostoros-völgy [8088.3, 2010, MCs]. Lébény: Pintér-Hanyban a Kimlei csatorna és a Herceg-csatorna összefolyásától É-ra illetve D-re eső réteken, ritka [8269.4, 2014, HGy]. Nagykereki: Barát-ér [8896.2, 2006, KG]. Novaj: Homokos-tető, É-i lejtőn [8188.2, 2010, MCs].

375. Dianthus armeria L. - Eger-Felnémet: Tó-lápa [8088.3, 2010, MCs]. Gyöngyösoroszi: Bárány-domb déli részén [8185.3, 2006, MCs]. Szuhafő: Kastély-bérc [7588.4, 2011, MÁ].

389. Eranthis hyemalis (L.) Salisb. - Debrecen: Nagyerdei park [8495.2, 2017, NT, TA].

391. Nigella arvensis L.- Hatvan: kisgombosi fás legelő [8284.3, 2009, MÁ].

395. Actaea spicata L.- Alsószuha: Bakóc-völgy [7689.1, 2009, MÁ].

397. Caltha palustris L. - Lovasberény: Alsó-rét falu felőli része [8677.3, 2015, KGK], Kenderföldek [8677.3, 2017, KGK]. Székesfehérvár: 81-es úttól keletre mély fekvésű rét [8776.3, 2015, KGK], Jancsár-völgy [8776.4, 2011, KGK].

409. Anemone sylvestris L.- Budapest: Széchenyi-hegy [8579.2, 2015, MÁ]. 
424. Adonis vernalis L. - Létavértes: államhatár melletti gyep [8697.3, 1990, KG]. Székesfehérvár: 811-es út és a Pátkai-víztározó között, löszgyepfolton [8777.1, 2015, KGK]. Velence: Csont-rét [8777.2, 2015, KGK].

426. Adonis flammea Jacq. - Székesfehérvár: Aszal-völgy mellett, bioszántón [8776.4, 2016, KGK]. Pátka: Páskom, szántóföld szegélye [8776.2, 2016, KGK] és Tikmony-völgy, szántóföld szegélye [8776.2, 2016, KGK].

427. Adonis aestivalis L. - Kánya: Tab felé, vetés szélén [9274.3, 2016, NT].

436. Ranunculus pedatus Waldst. et Kit. - Debrecen: Egyetem tér [8495.2, 2000, MVA]. Mezőkövesd: Kánya-patak menti gyepekben [8289.4, 2014, MCs]. Tiszalök: Lökös-dúlő [7994.4, 2014, MCs].

444. Ranunculus sceleratus L. -Gyöngyössolymos: a galyatetői elágazás mellett, vizenyős talajú vágásnövényzetben [8185.2, 2004, MCs]. Nagycsepely: a halastó közelében, patakmederben [9272.4, 2016, NT]. Tiszalök: Lökös-dűlő [7994.4, 2014, MCs].

451. Ranunculus polyanthemos L.- Zádorfalva: Ragyás-szőlő [7688.2, 2009, MÁ].

455. Ranunculus acris L. - [8289.2, 2014, MCs]. [7994.4, 2014, MCs].

459. Myosurus minimus L. - Mezőkövesd: Kánya-patak menti gyepekben [8289.4, 2014, MCs]. Székesfehérvár: Új-gáti-parrag [8877.1, 2012, KGK].

465. Thalictrum flavum L. - Tiszalök: Lökös-dúlő [7994.4, 2014, MCs].

466. Thalictrum lucidum L. - Nádudvar: Sároséri-fócsatorna kubik [8592.1, 2016, KG].

471. Mahonia aquifolium agg. - Gyöngyös: Visontai-hegy oldala és Visonta: Bajna-dűlő [8285.2, 2010, MCs].

479. Papaver rhoeas L. - [8680.1, 2011, MCs].

480. Papaver dubium L. - Gömörszőlős: Pálykás [7688.2, 2010, MÁ]. Gyöngyöspata: Havas, lejtősztyeppréten [8184.4, 2008, MCs]. Hortobágy: Százköblös [8492.2, 2016, KG], Juhoshát [8392.4, 2016, KG] és Zám, Kenderhátó-telek [8491.4, 2016, KG]. Szögliget: Szádvár oldalában [7490.3, 2007, MCs].

485. Corydalis cava L. - [8776.2, 2016, KGK].

488. Corydalis solida L. - [7595.2, 2011, MCs].

492. Fumaria schleicheri Soy.-Will. - [7793.1, 2012, MCs]. [7893.1, 2005, MCs].

500. Sisymbrium loeselii L. - Budapest: M3 Szilas pihenőhely [8480.2, 2011, MCs].

503. Arabidopsis thaliana (L.) Heynh. - [8480.2, 2011, MCs]. [8269.4, 2016, HGy]. [8390.2, 2014, MCs]. [7993.3, 2014, MCs].

506. Bunias orientalis L. - Törökbálint: M0 0. km mellett [8579.3, 2011, MCs].

509. Erysimum repandum L. - Lébény: Nagy-dombon találtam néhány tövet (Pintérszigettől K-i irányban) száraz homokos területen [8270.1, 2016, HGy].

510. Erysimum diffusum Ehrh. - Bekecs: Közép-hegy [7893.1, 2007, MCs].

514. Erysimum odoratum Ehrh. - Tarnaszentmária: Vár-hegy [8187.1, 2005, MCs].

516. Hesperis tristis L. - Hortobágy: Zám, Kenderhátó-telek [8491.4, 2016, KG] és Juhoshát [8392.4, 2016, KG].

522. Chorispora tenella (Pall.) DC. - Kecskemét: református temető (Budai út), egy elhanyagolt sírhanton néhány tő [9084.3, 2016, NT, TA]. Kecskemét-Szentkirály: a 44-es és a 4622-es út padkáján tömeges [9084.4, 9085.3, 9085.4, 2017, NT, TA].

525. Barbarea stricta Andrz. - Lébény: Urhanya-csatorna és a Tőzeg-csatorna összefolyásától D-i irányba lévő Figurákban az Urhanya-csatorna partján, valamint Rábcakapi: Rábca és a Gátőrházi üzemvíz csatorna összefolyásánál néhány tő [8269.4, 2015, HGy].

538. Cardamine parviflora L. - Lébény: Polgári-Pintér Hanyban a bormászpusztai úttól ÉNY-i irányban lévő rét együttes középső részén találtam 5 tőből álló állományát [8269.4, 2016, HGy]. Tiszalök: Lökös-dúlő [7994.4, 2014, MCs]. 
539. Cardamine hirsuta L. - Debrecen: Egyetem tér [8495.2, 2010, MVA]. Lébény: napfénynek erősen kitett erdészeti utak mentén [8269.2, 2016, HGy]. Rábcakapi: a Rábca töltésének déli kitettségű meleg oldalain leginkább a töltéskorona mellett [8269.4, 2016, HGy].

542. Cardamine pratensis L. - Lébény: Polgári-Pintér Hany, idős égeresekben (Urhanyi Figurák) állomány alatt, nedves réteken, szórványos [8269.4, 2015, HGy].

545. Cardaminopsis arenosa (L.) Hayek - Dubicsány: Zsupunyó-völgy Dienes-hegyi oldalában [7788.2, 2013, MCs].

547. Arabis glabra (L.) Bernh. - Gödöllő: Juharos-bérc [8482.2, 2006, MCs].

549. Arabis recta Vill. - Rábcakapi: Bősárkány-Rábcakapi töltésszakaszon, a Rábca töltésének déli oldalában szórtan fordul elő [8269.4, 2016, HGy].

556. Alyssum alyssoides L. - [8269.4, 2016, HGy]. [9273.1, 2016, NT]. [7490.3, 2007, MCs].

560. Berteroa incana (L.) DC. - [8299.1, 2014, MCs]. [7695.2, 2007, MCs].

567. Rorippa sylvestris (L.) Besser - Polgár: M3 Polgári pihenőhely [8192.4, 2011, MCs].

569. Draba nemorosa L. - Rábcakapi: Bősárkány-Rábcakapi vonalon az árvízvédelmi töltés déli kitettségű oldalában több helyen [8269.4, 2015, HGy].

571-573. Erophila verna agg. - [8284.4, 2011, MCs]. [8289.2, 8289.4, 2014, MCs]. [8092.2, 2014, MCs].

574.1. Camelina microcarpa Andrz. ex DC. subsp. microcarpa - Domaháza: Cé-lápa mellett [7886.2, 2013, MCs].

583. Thlaspi perfoliatum L. - [8285.2, 2010, MCs]. [8188.2, 2010, MCs].

602. Cardaria draba (L.) Desv. - [8284.4, 2011, MCs]. [8088.3, 2010, MCs].

615. Brassica ×napus L. - Besenyőtelek: Tagosok, gabonatáblában [8288.4, 2008, MCs]. Mezőtárkány: Isten mezeje és Nagy-fenék, ugaron [8389.1, 2008, MCs]. Nyírcsaholy: Szentmiklósi-dűlő, lovasudvar [8099.4, 2014, MCs].

635. Hylotelephium telephium (L.) H.Ohba subsp. maximum (L.) H.Ohba - Kisnána: Macskavár [8186.4, 2007, MCs].

643. Sedum acre L. - Nagyiván: Sároséri-főcsatorna [8591.2, 2016, KG]. Tihany: Gödrös, Diósi-rétek fölött, kis pihenőnél [9073.3, 2007, MCs].

654. Ribes uva-crispa L. - Szólád: Nezde, Almán-tető [9273.1, 2016, NT].

711. Sanguisorba officinalis L. - Aba: a Nádor-csatornához vezető dűlőtől D-re levő rét [8976.4, 2016, KGK]. Székesfehérvár: Császár-víz jobb partján levő rét [8776.4, 2016, KGK]. Pátka: Pátkai-víztározótól ÉNy-ra levő mély fekvésű rét [8776.2, 2016, KGK] és Zámolyivíztározó zárógátja mentén [8776.2, 2017, KGK].

712. Sanguisorba minor Scop. - Vecsés: M0 autópálya mellett, Ferihegynél [8581.4, 2011, MCs]. 719. Potentilla rupestris L. - Aggtelek: Kardos-völgy, csarabosban [7589.3, 2013, MCs].

725. Potentilla reptans L. - [7886.2, 2013, MCs].

730. Potentilla recta L. - Aggtelek: Kardos-völgy, csarabosban [7589.3, 2013, MCs].

731. Potentilla heptaphylla L. - Abod: Fazekas-tetőtől DNy-ra [7690.2, 2014, MCs]. Gyöngyöspata: Vár-hegy és Gereg [8184.4, 2010, MCs]. Gyöngyössolymos: Tarma-oldal [8185.4, 2007, MCs]. Gyöngyöstarján: Hosszú-hegy [8185.3, 2010, MCs]. Tállya: Patócshegy [7793.3, 2008, MCs].

732. Potentilla patula Waldst. et Kit. - Mezőkövesd: Egyház-rét [8289.2, 2014, MCs] és Kánya-patak menti gyepekben [8289.4, 2014, MCs].

736. Fragaria viridis Duchesne - [9073.3, 2007, MCs]. [7595.2, 2009, MCs]. [8180.3, 2007, MCs].

737. Fragaria moschata Duchesne - Gyöngyös: Peres-vágás [8186.1, 8186.3, 2013, MCs]. Gyöngyöspata-Gyöngyöstarján: Havas, cseres-tölgyesben [8184.4, 2008, MCs]. Gyöngyössolymos: Nagy-Halmaj [8185.2, 2013, MCs].

758. Malus sylvestris (L.) Mill. - Szuhafő: Szuha-patak égerligete [7588.4, 2009, MÁ].

762. Sorbus aucuparia L. - Aggtelek: Szőlőhegy [7589.1, 2013, MCs].

772. Sorbus torminalis (L.) Crantz. - Szentistvánbaksa: Bika-rét [7792.3, 2005, MCs]. 
835. Lembotropis nigricans (L.) Griseb. - Érsekvadkert: Göröc [7981.3, 2012, MÁ].

837. Corothamnus procumbens (Waldst. et Kit.) C.Presl - Gyöngyös: Sár-hegy [8285.2, 2008, MCs].

841. Chamaecytisus albus (Hacq.) Rothm. - Jósvafő: Szőlő-hegy [7589.1, 2013, MCs].

842. Chamaecytisus austriacus (L.) Link - Szuhafö: Virág-domb [7588.4, 2009, MÁ].

844. Chamaecytisus ratisbonensis (Schaeff.) Rothm. - Budapest: M0 Megyeri-híd pesti hídfője mellett [8380.4, 2011, MCs]. Gyöngyös: Sár-hegy [8285.2, 2008, MCs].

846. Chamaecytisus triflorus (Lam.) Skalická - Gyöngyössolymos: Tarma-oldal [8185.4, 2007, MCs].

848. Genista germanica L. - Domaháza: Zsellyéte [7886.2, 2013, MCs].

849. Genista pilosa L. - Gyöngyös: Visontai-hegy [8285.2, 2010, MCs]. Szuhafő: Petőháza [7688.2, 2011, MÁ].

861. Colutea arborescens L. - Gyöngyöstarján: Hosszú-hegy [8185.3, 2010, MCs].

871. Astragalus asper Wulfen - Pátka: Páskom, lucernatábla szélén [8776.2, 2016, KGK].

877. Glycyrrhiza echinata L. - Tiszadorogma: Keszeges és Nagy-vájás között, mocsárréten [8291.3, 2014, MCs].

879. Amorpha fruticosa L. - [8285.2, 2010, MCs].

887. Vicia hirsuta (L.) S.F.Gray - [8299.1, 2014, MCs]. [7894.1, 2005, MCs]. [8480.2, 2011, MCs]. [8284.4, 2011, MCs]. [7693.2, 2014, MCs]. [8190.4, 2011, MCs]. [8184.4, 2008, MCs]. [7589.1, 2014, MCs]. [7893.2, 2005, MCs]. [7792.4, 2005, MCs]. [8192.4, 2011, MCs]. [8290.4, 2014, MCs]. [7793.3, 2008, MCs]. [8390.2, 2014, MCs].

888. Vicia tetrasperma (L.) Schreb. - Aggtelek: Kardos-völgy, csarabosban [7589.3, 2013, MCs]. Gyöngyös: Sár-hegy, Visontai-hegy [8285.2, 2010, MCs]. Gyöngyösoroszi: Báránydomb déli részén és Gyöngyöstarján: Bólya [8185.3, 2006, MCs]. Gyöngyöstarján: Káva [8184.2, 2006, MCs]. Hatvan: kisgombosi fás legelő [8284.3, 2009, MÁ]. Mikóháza: NagyPolyán [7595.2, 2010, MCs]. Szentistván: Batúz-tanyától É-ra [8290.4, 2014, MCs]. Tiszadorogma: Közös legelők [8291.3, 2014, MCs].

891. Vicia pisiformis L. - Eger-Felnémet: Tó-lápa és a Tárkányi-patak menti dombon, Felsőtárkány, Ostoros-völgy [8088.3, 2010, MCs]. Feldebrő: Cser, tisztáson [8187.3, 2007, MCs].

892. Vicia dumetorum L. - Domaháza: Cé-lápa mellett [7886.2, 2013, MCs]. Gyöngyöspata: Csárda-puszta erdeje [8184.3, 2006, MCs].

894. Vicia cassubica L. - Domaháza: Cé-lápa mellett [7886.2, 2013, MCs]. Feldebrő: Cser, völgyalji üde erdő [8187.3, 2007, MCs]. Gyöngyöspata: Havas [8184.4, 2008, MCs]. Gyöngyöstarján: Káva [8184.2, 2006, MCs]. Tállya: Patócs-hegy [7793.3, 2008, MCs].

896. Vicia villosa Roth - [8284.3, 2009, MÁ]. [8099.4, 2014, MCs]. [8196.1, 2011, MCs]. [8192.4, 2011, MCs]. [7793.3, 2008, MCs].

897. Vicia tenuifolia Roth - Abasár: Rónya-bérc [8186.3, 2013, MCs]. Feldebrő: Cser, tisztáson [8187.3, 2007, MCs]. Gyöngyöstarján: Öreg-hegy és Diós között [8185.3, 2010, MCs]. Mád: Birsalmás-tető [7893.2, 2005, MCs]. Novaj: a belterülettől É-ra, egykori homokkő-bányában [8188.2, 2010, MCs]. Pásztó: Város-erdő [8184.1, 2007, MCs]. Szentistvánbaksa: Bika-rét [7792.3, 2005, MCs]. Tállya: Palota-hegy [7793.3, 2005, MCs]. Tolcsva: Vár-hegy [7794.2, 2008, MCs].

900. Vicia lathyroides L. - Abaújszántó: Sátor-hegy alatt, szőlősorközben [7793.1, 2012, MCs]. Abod: Fazekas-tetőtől DNy-ra és Szendrőlád: Csákány [7690.2, 2014, MCs]. Átány: a Görbe-ér menti gyepekben [8388.2, 2014, MCs] és a Hanyi-éri-főcsatorna Vágóhídi-hídjától DK-re, kis kaszált mélyedésben [8388.3, 2014, MCs]. Budapest: M3 Szilas pihenőhely [8480.2, 2011, MCs]. Domaháza: gyepekben sokfelé [7886.2, 2013, MCs]. Ecséd: M3 Ecsédi pihenőhely [8284.4, 2011, MCs]. Egerfarmos: a belterülettől közvetlenül D-re [8289.3, 2014, MCs]. Egerszólát: Ádám-tető [8187.2, 2008, MCs]. Gyöngyös: Visontai-hegy és Visonta: Bajna-dűlő [8285.2, 2010, MCs]. Hatvan: kisgombosi fás legelő [8284.3, 2009, MÁ]. 
Mezőkövesd: Kánya-patak felé lévő gyepekben [8289.2, 8289.4, 2014, MCs]. Mikóháza: Nagy-Polyán [7595.2, 2010, MCs]. Novaj: a belterülettől É-ra parlagokon és erodált talajú szárazgyepekben [8188.2, 2010, MCs]. Nyírcsaholy: Szentmiklósi-dúlő, lovasudvar [8099.4, 2014, MCs]. Polgár: M3 Polgári pihenőhely [8192.4, 2011, MCs]. Szigetszentmiklós: M0 Csepeli pihenőhely [8680.1, 2011, MCs]. Szuhogy: Nagy-hegy alja, parlagon [7689.2, 2013, MCs]. Tiszadob: Ó-Kenéz [7993.3, 2014, MCs] és Horgoló [8092.2, 2014, MCs]. Tiszadorogma: Közös legelők [8391.1, 2014, MCs]. Vecsés: M0 autópálya mellett, Ferihegynél [8581.4, 2011, MCs].

901.1. Vicia pannonica Crantz. subsp. pannonica - Besenyőtelek: Tepély-puszta [8389.1, 2008, MCs]. Szólád: Köpü-Horog [9273.1, 2016, NT]. Kereki: temető melletti gyep [9173.4, 2016, NT].

901.2. Vicia pannonica Crantz subsp. striata (M Bieb.) Nyman - Serényfalva: Keleméripatak és a Kelemérre vezető műút között [7688.3, 2009, MÁ].

903. Vicia grandiflora Scop. - [8192.4, 2011, MCs]. [8290.4, 2014, MCs]. [8291.3, 2014, MCs].

905. Vicia sepium L. - Gyöngyöstarján: erdős sövényben a Hosszú-hegy D-i oldalában, egykori szőlő-legelő határ [8185.3, 2010, MCs].

908. Vicia angustifolia L. - [8382.4, 2011, MCs]. [7886.2, 2013, MCs]. [8285.2, 2010, MCs]. [8194.2, 2011, MCs]. [7589.1, 2013, MCs]. [8188.2, 2010, MCs]. [8192.4, 2011, MCs]. [7883.4, 2011, MÁ]. [7793.3, 2008, MCs]. [8579.3, 2011, MCs].

911. Lathyrus nissolia L. - Mikóháza: Nagy- és Kis-Polyán [7595.2, 7595.4, 2010, MCs].

912. Lathyrus pratensis L. - Gyöngyös: Sár-hegy, Visontai-hegy, Cseplye-oldal [8285.2, 2010, MCs].

921. Lathyrus sylvestris L.- Ludányhalászi: Agyagos-hegy [7883.3, 2011, MÁ].

926. Lathyrus lactaeus (M.Bieb.) Wissjul. - Jósvafő: Szőlő-hegy [7589.1, 2013, MCs]. Tállya: Patócs-hegy [7793.3, 2008, MCs].

928. Lathyrus niger (L.) Bernh. - Eger: Eged alja, Eger-Felnémet, Tó-lápa és Felsőtárkány: Ostoros-völgy [8088.3, 2010, MCs].

935. Ononis arvensis L. - Domaháza: Gortva-tető [7886.2, 2013, MCs].

947. Medicago falcata L. - [8382.4, 2011, MCs]. [7886.2, 2013, MCs]. [8284.4, 2008, MCs]. [8196.1, 2011, MCs].

948. Medicago lupulina L. - [8495.4, 2004, MCs]. [8192.4, 2011, MCs]. [8680.1, 2011, MCs]. [7490.2, 2014, MCs].

950. Medicago prostrata Jacq. - Eger-Felnémet: Bajusztól É-ra [8088.3, 2010, MCs].

953. Medicago minima (L.) L. - Budapest: M3 Szilas pihenőhely [8480.2, 2011, MCs]. Lébény: Ottó-major, bolygatott száraz gyepekben gyakran előfordul [8269.2, 2016, HGy]. Vecsés: M0 Alacska pihenőhely [8681.2, 2011, MCs].

958. Trifolium hybridum L. - Gyöngyöstarján: Bólya, fiatal szántóparlagon [8185.3, 2010, MCs]. Tornanádaska: Temető-dűlő, kaszált parlagon [7490.2, 2014, MCs].

959. Trifolium micranthum Viv. - Hencida: Csere-erdő [8796.3, 2016, MVA].

961. Trifolium aureum Pollich - Besenyőtelek: Bíbic-legelő, kis löszös háton [8388.1, 2014, MCs]. Gyöngyöstarján: Hosszú-hegy és Öreg-hegy [8185.3, 2010, MCs]. Hatvan: kisgombosi fás legelő [8284.3, 2009, MÁ]. Mikóháza: Nagy-Polyán [7595.2, 2010, MCs]. Novaj: a belterülettől Éra, gyepekben [8188.2, 2010, MCs]. Szalmatercs: Cseres-oldal [7883.4, 2011, MÁ].

962. Trifolium dubium Sibth. - Nyírcsaholy: Szentmiklósi-dűlő, lovasudvar [8099.4, 2014, MCs].

963. Trifolium campestre Schreb. - [7690.2, 2014, MCs]. [7894.1, 2005, MCs]. [7886.2, 2013, MCs]. [8194.2, 2011, MCs]. [7589.1, 2014, MCs]. [7893.1, 2004, MCs]. [7595.4, 2009, MCs]. [8188.2, 2010, MCs]. [8099.4, 2014, MCs]. [8192.4, 2011, MCs]. [7689.2, 2013, MCs]. [8290.4, 2014, MCs]. [8291.3, 2014, MCs]. [8579.3, 2011, MCs].

964. Trifolium strictum L. - Tiszavalk: Urak legelője [8390.2, 2014, MCs].

965. Trifolium repens $\mathrm{L}$ - $[$ [7589.3, 2013, MCs]. [8088.3, 2010, MCs]. 
966. Trifolium angulatum Waldst. et Kit. - Szentistván: Salamon-major és Batúz-tanya mellett, valamint Tiszabábolna, Orosz-ér és Tiszavalki-főcsatorna között [8290.4, 2014, MCs]. Tiszadorogma: Közös legelők [8291.3, 2014, MCs].

967. Trifolium montanum L. - Aggtelek: Kardos-völgy, csarabosban [7589.3, 2013, MCs]. Domaháza: Gortva-tető [7886.2, 2013, MCs].

968. Trifolium retusum L. - Mezőkövesd: Borjú-kút [8289.2, 2014, MCs]. Szentistván: Salamon-major mellett [8290.4, 2014, MCs]. Tiszabábolna: Nádas-fertő [8390.2, 2014, MCs]. Tiszadorogma: Közös legelők [8291.3, 2014, MCs].

970.1. Trifolium fragiferum L. subsp. fragiferum - Debrecen: Tócóvölgy vasútállomástól Éra, legelőn [8495.4, 2004, MCs].

972. Trifolium rubens L. - Jósvafő: Szőlő-hegy [7589.1, 2013, MCs]. Ludányhalászi: Agyagoshegy [7883.3, 2011, MÁ].

973. Trifolium alpestre L. - Aggtelek: Kardos-völgy, csarabosban [7589.3, 2013, MCs]. Bekecs: Közép-hegy [7893.1, 2007, MCs]. Érsekvadkert: Göröc [7981.3, 2012, MÁ].

975. Trifolium ochroleucon Huds. - Gyöngyöspata: Ferge-rét és Gereg [8184.4, 2010, MCs]. Gyöngyöstarján: Hosszú-hegy [8185.3, 2010, MCs]. Jósvafő: Köves-bérc [7589.1, 2014, MCs]. Nógrádkövesd: a falutól ÉNy-ra, felhagyott kaszálón [8182.1, 2008, MCs].

977. Trifolium medium L. - Debrecen: Tócóvölgy vasútállomástól É-ra, legelőn [8495.4, 2004, MCs]. Gyöngyöstarján: Bólya, erdős sövényben [8184.4, 2010, MCs]. Mikóháza: KisPolyán, legelőn [7595.4, 2009, MCs].Novaj: a belterülettől É-ra, félszáraz és üdébb gyepekben [8188.2, 2010, MCs].

978. Trifolium pratense L. - [8088.3, 2010, MCs]. [8285.2, 2010, MCs]. [7589.1, 2014, MCs]. [8188.2, 2010, MCs].

980. Trifolium striatum L. - Szentistván: Salamon-major és Batúz-tanya mellett, valamint Tiszabábolna, Orosz-ér és Tiszavalki-főcsatorna között [8290.4, 2014, MCs]. Tiszavalk: Urak legelője [8390.2, 2014, MCs].

983. Trifolium arvense L. - [8190.4, 2011, MCs]. [9273.3, 2016, NT]. [8269.2, 8270.3, 8269.4, 2016, HGy]. [8290.4, 2014, MCs]. [8680.1, 2011, MCs]. [7590.3, 2013, MCs]. [7689.2, 2013, MCs].

984. Dorycnium herbaceum Vill. - Mikóháza: Nagy-Polyán, legelőn [7595.2, 2009, MCs].

985. Dorycnium germanicum (Gremli) Rikli - Budapest: M0 Megyeri-híd pesti hídfője mellett [8380.4, 2011, MCs].

988. Lotus tenuis Waldst. et Kit. - Szentistván: Salamon-major és Batúz-tanya mellett [8290.4, 2014, MCs].

992. Securigera varia (L.) Lassen - [7883.3, 2011, MÁ]. [7883.4, 2011, MÁ].

994. Anthyllis vulneraria L. - Székesfehérvár: Aszal-völgy [8776.4, 2016, KGK].

1003. Oxalis stricta L.- Gyöngyös: Sár-hegy [8285.2, 2008, MCs].

1008. Geranium phaeum L.- Alsószuha: Bakóc-völgy [7689.1, 2012, MÁ].

1009. Geranium sanguineum L.- Sajókaza: Szár-hegy [7789.2, 2012, MÁ].

1011. Geranium pratense L. - Monok: Hosszú-völgy és Oláh-völgy [7792.4, 2016, MCs].

1014. Geranium columbinum L. - Abod: Fazekas-tetőtől DNy-ra [7690.2, 2014, MCs]. Gödöllő: Látó-hegy [8382.4, 2006, MCs]. Gömörszőlős: Bikás-tető [7688.2, 2009, MÁ]. Szalmatercs: Cseres-oldal [7883.4, 2011, MÁ].

1020. Geranium molle L. - Abaújszántó: Sátor-hegy alatt, szőlősorközben [7793.1, 2012, MCs]. Besenyőtelek: Bíbic-legelő [8388.1, 2014, MCs]. Budapest: M3 Szilas pihenőhely [8480.2, 2011, MCs]. Szentistván: Szék lápa mellett [8290.4, 2014, MCs]. Vecsés: M0 Alacska pihenőhely [8681.2, 2011, MCs].

1021. Geranium pusillum Burm.f. - [8185.3, 2007, MCs]. [8289.3, 2014, MCs]. [8099.4, 2014, MCs]. [7490.3, 2007, MCs].

1023. Erodium cicutarium (L.) L'Hér. - [8299.1, 2014, MCs]. 
1025. Erodium ciconium (Jusl.) L'Hér. - Mezőkövesd: Egyház-rét [8289.2, 2014, MCs].

1026. Tribulus terrestris L. - Debrecen: Borbiró tér, járdarepedésben [8495.2, 2016, MVA].

1027. Linum catharticum L. - Alsószuha: Lác-oldal [7689.1, 2009, MÁ]. Domaháza:

Zsellyéte [7886.2, 2013, MCs]. Monok: Zsebrik [7792.4, 2005, MCs].

1030. Linum flavum L. - Domaháza: Hangony-tető [7886.2, 2013, MCs].

1031. Linum tenuifolium L. - Székesfehérvár: Pénzverő-völgy, löszgyepfolt [8776.4, 2015, KGK].

1032. Linum hirsutum L. - Lovasberény: Kazal-hegy [8777.1, 2015, KGK].

1042. Euphorbia maculata L. - Búcsúszentlászló: Arany János utca, járdarepedésben [9267.2, 2016, MVA].

1049. Euphorbia glareosa Pall. - Hatvan: kisgombosi fás legelő [8284.3, 2009, MÁ].

1052. Euphorbia epythymoides L. - Apc: Tarcod-hegy [8184.3, 2007, MCs]. Felsőnyárád:

Kővágó [7689.4, 2009, MÁ]. Pásztó: Kerek-domb [8184.1, 2007, MCs].

1058. Euphorbia salicifolia Host - Gyöngyös: Visontai-hegy [8285.2, 2010, MCs].

1061.1. Euphorbia esula L. - Domaháza: Kovács ortványa mellett, parlagon [7886.2, 2013,

MCs]. Eger-Felnémet: Tó-lápa és Felsőtárkány: Ostoros-völgy, Tiba alja-dűlő [8088.3, 2010,

MCs]. Gyöngyöstarján: Bólya, kaszált szántóparlagon [8184.4, 2010, MCs]. Jósvafő: Gergebérc [7589.1, 2014, MCs]. Rudabánya: bányaoldalban, a Kápolna-hegy mellett [7689.2, 2013, MCs]. Tiszadob: Ó-Kenéz [7993.3, 2014, MCs].

1062. Euphorbia virgata Waldst. et Kit. - Eger-Felnémet: parlagokon és szárazgyepekben [8088.3, 2010, MCs]. Fony: Csepegő-forrás körüli gyepekben [7593.4, 2014, MCs]. Jósvafő: Szőlő-hegy [7589.1, 2013, MCs]. Visonta: Bajna-dúlő [8285.2, 2010, MCs].

1064. Euphorbia peplus L. - Monok: belterület, a polgármesteri hivatal mellett [7792.4, 2016, MCs].

1068.1. Euphorbia falcata L. - Gömörszőlős: belterület, építkezési agyagdombon [7688.2, 2016, MCs].

1075.1. Polygala vulgaris L. subsp. vulgaris - Domaháza: Zsellyéte és Körte-völgy között [7886.2, 2013, MCs].

1076. Polygala comosa Schkuhr - Abod: Fazekas-tetőtől DNy-ra [7690.2, 2014, MCs]. Gyöngyöspata: Ferge-rét és Gereg [8184.4, 2010, MCs]. Kereki: temető melletti gyep [9173.4, 2016, NT]. Novaj: Homokos-tető É-i lejtőin [8188.2, 2010, MCs]. Teleki: Templomdülő [9272.2, 2016, NT].

1083. Acer tataricum L. - Aggtelek: Szőlőhegy [7589.1, 2013, MCs]. Hatvan: kisgombosi fás legelő [8284.3, 2009, MÁ].

1090. Impatiens parviflora DC. - Gyöngyöspata: János vára [8184.2, 2006, MCs].

1098. Staphylea pinnata L. - Sajóvelezd: Vár-hegy [7788.2, 2013, MCs].

1121. Lavatera thuringiaca L. - Lébény: Farkas-dombon szálanként [8270.3, 2016, HGy].

Rózsaszentmárton: Tarcodi-pincék felett, törpemandulásban [8184.3, 2007, MCs].

1124. Althaea cannabina L. - Balatonalmádi: Szömörce utca, telekhatáron [8974.3, 2016, MVA].

1130. Hibiscus trionum L. - [8188.2, 2010, MCs].

1135. Thymelaea passerina (L.) Coss. et Germ. - Gyöngyös: Visontai-hegy [8285.2, 2010, MCs].

1142. Hypericum tetrapterum Fr. - Lébény: Polgári-Pintér Hany ligeterdeinek szélében, magassásos növényzetben [8269.4, 2016, HGy].

1145. Hypericum hirsutum L. - Gyöngyöstarján-Gyöngyöspata: Havas, cseres-tölgyesben [8184.4, 2008, MCs]. Hernádpetri: Agyagos-oldal feletti erdőkben [7593.1, 2006, MCs].

1147. Hypericum montanum L. - Gyöngyös: Sár-hegy [8285.2, 2010, MCs]. Gyöngyöspata: Ferge-rét és Gyöngyöstarján: Bólya-tető [8184.4, 2010, MCs].

1152. Viola kitaibeliana Roem. et Schult. - Gyöngyöstarján: Nagy-Kocsordos [8184.4, 2006, MCs]. Mezőkövesd: Egyház-rét [8289.2, 8289.4, 2014, MCs]. Nyírcsaholy: Szentmiklósidűlő, lovasudvar [8099.4, 2014, MCs]. 
1153. Viola alba Besser - Mikóháza: Nagy-Polyán, gyertyános-kocsányos tölgyesben [7595.2, 2011, MCs].

1156. Viola mirabilis L.- Hatvan: kisgombosi fás legelő [8284.3, 2009, MÁ].

1158. Viola hirta L. - Aggtelek: Kardos-völgy, csarabosban [7589.3, 2013, MCs]. Kisnána: Macskavár [8186.4, 2007, MCs]. Nagytarcsa: Küdői-hegy [8481.4, 2006, MCs]. Zádorfalva: Iván-tető, Ragyás-szőlő [7688.2, 2009, MÁ].

1161. Viola reichenbachiana Jord. - Gyöngyös: Visontai-hegy oldala [8285.2, 2010, MCs]. Mikóháza: Nagy-Polyán, gyertyános-kocsányos tölgyesben [7595.2, 2011, MCs]. Nagytarcsa: Küdői-hegy [8481.4, 2006, MCs].

1164.1. Viola canina L. subsp. canina - Abod: Fazekas-tetőtől DNy-ra [7690.2, 2014, MCs]. Domaháza: Bikk és Gortva-tető [7886.2, 2013, MCs]. Eger-Felnémet-Felsőtárkány: Ostorosvölgy [8088.3, 2010, MCs]. Gyöngyös: Cseplye-oldal, Visontai-hegy oldala [8285.2, 2010, MCs]. Mikóháza: Nagy-Polyán, legelőn [7595.2, 2010, MCs]. Novaj: Homokos-tető É-i lejtője [8188.2, 2010, MCs]. Rudabánya: Kápolna-hegy és Csák-rét között, legelőn [7689.2, 2013, MCs].

1164.2. Viola canina L. subsp. montana (L.) Hartm. - Eger-Felnémet: Galagonyás-dűlő [8088.3, 2010, MCs]. Gyöngyös: Sár-hegy [8285.2, 2008, MCs]. Gyöngyöspata: Antal-hegy [8184.3, 2006, MCs].

1165. Viola pumila Chaix - Tiszalök: Lökös-dűlő [7994.4, 2014, MCs].

1169. Helianthemum ovatum (Viv.) Dunal in DC. - Gyöngyös: Cseplye-oldal [8285.2, 2010, MCs].

1180. Thladiantha dubia Bunge - Hajdúböszörmény: temető [8394.2, 2016, MVA]. Tiszafüred: Igari út [8390.4, 2016, MVA].

1182. Bryonia alba L. - Gyöngyöspata-Gyöngyöstarján: Havas alja, Nagy-Kocsordos felett és Gereg-hegy, valamint Gyöngyöstarján: Hagymás-völgy [8184.4, 2006, MCs]. Gyöngyöstarján: Merőkő-völgy Hosszú-hegy felöli oldala [8185.3, 2010, MCs].

1195. Lythrum virgatum L. - Kelemér: Doszpoty-völgy alján lévő mocsárréten [7688.4, 2013, MCs]. 1197. Lythrum hyssopifolia L. - Tiszalök: Ital-szék-dűlő [7994.4, 2014, MCs].

1198. Lythrum tribracteatum Salzm. in Spreng. - Jánoshida: Tót-Kéri-tanyák [8585.4, 2016, MVA]. Jászjákóhalma: Bakter-szög [8485.4, 2016, MVA].

1222. Epilobium montanum L. - Alsószuha: Bakóc-völgy [7689.1, 2009, MÁ]. Hernádpetri: Agyagos-oldal felett, a Borsod-patak mentén [7593.1, 2006, MCs].

1241. Sanicula europaea L. - Valkó: Szent Pál-hegy [8482.2, 2006, MCs].

1244. Eryngium planum L. - Nádudvar: Árkus és Hortobágy összefolyása $(0+200$ zsilip mellett) [8592.2, 2016, KG].

1250. Chaerophyllum temulum L. - Aldebrő: Cseralja, rontott keményfaligeterdőben [8187.3, 2007, MCs]. Hatvan: kisgombosi fás legelő [8284.3, 2009, MÁ]. Pécel: Vár-hegy [8482.3, 2006, MCs]. Visonta: Bajna-dúlő [8285.2, 2010, MCs].

1258. Smyrnium perfoliatum L. - Székesfehérvár: Császár-víz-völgy, Kőrakás-hegy mellett [8776.4, 2016, KGK].

1265. Berula erecta (Huds.) Coville - Nagycsepely: Nádasdi-rét [9272.4, 2016, NT].

1266. Libanotis pyrenaica (L.) Bourg. - Szuhogy: Somod-dűlő [7590.3, 2013, MCs].

1269. Seseli annuum L. - Érsekvadkert: Göröc [7981.3, 2012, MÁ]. Mád: Birsalmás-tető [7893.2, 2005, MCs].

1271. Seseli varium Trevir. - Aggtelek: Kardos-völgy, csarabosban [7589.3, 2013, MCs]. Jósvafő: Szőlő-hegy [7589.1, 2013, MCs]. Szuhogy: Somod-dűlő [7590.3, 2013, MCs].

1272. Seseli osseum Crantz. em. Simonk. - Kisnána: Macskavár [8186.4, 2007, MCs]. Sajókaza: Szár-hegy [7789.2, 2009, MÁ].

1273. Oenanthe aquatica (L.) Poir. - Rábcakapi: belvizes foltokban, valamint Tárnokréti: Herceg-csatorna áteresze felett felduzzadt pangóvízben, az Öreg-Rábca medrében, lassú folyású csatornák partjain [8269.4, 2016, HGy]. Tiszalök: Lökös-dűlő [7994.4, 2014, MCs]. 
1311. Peucedanum officinale L. - Hortobágy: vasútállomás és a takarmánykeverő közötti gyepfolt [8492.2, 2016, KGK]. Tiszadob: Ó-Kenéz [7993.3, 2014, MCs]. Tiszalök: Lökös-dűlő [7994.4, 2014, MCs].

1314. Peucedanum cervaria (L.) Lapeyr. - Jósvafő: Szőlő-hegy [7589.1, 2013, MCs].

1324. Torilis arvensis (Huds.) Link - [8185.2, 2013, MCs]. [8285.2, 2010, MCs].

1325. Torilis japonica (Houtt.) DC. - Feldebrő: Cser, telepített kocsánytalan tölgyesben [8187.3, 2007, MCs]. Hidasnémeti: Keserü-völgy [7493.3, 2006, MCs].

1351. Androsace elongata L. - Fony: Cigány-tövis [7693.2, 2014, MCs]. Mezőkövesd: Egyház-rét és Borjú-kút [8289.2, 2014, MCs].

1361. Anagallis arvensis L. - [7589.3, 2013, MCs]. [8088.3, 2010, MCs]. [8184.4, 2008, MCs]. [7595.2, 2010, MCs]. [9272.4, 2016, NT].

1362. Anagallis foemina Mill. - Felsőtárkány: Tiba alja [8088.3, 2010, MCs]. Visonta: Sárhegy [8285.2, 2010, MCs].

1366. Limonium gmelinii (Willd.) Kuntze subsp. hungaricum (Klokov) Soó - Tiszalök: Lökös-dűlő [7994.4, 2014, MCs].

1377. Syringa vulgaris L. - Nagyiván: Urbán-tanya helye [8491.4, 2016, KG]. Zádorfalva: Kis-erdő-tető [7688.2, 2014, MCs].

1383. Centaurium erythraea Raf. - Domaháza: Zsellyéte és Körte-völgy között, Bikk [7886.2, 2013, MCs]. Eger-Felnémet: parlagokon és félszáraz gyepekben [8088.3, 2010, MCs]. Gyöngyös: Cseplye-oldal és Visontai-hegy [8285.2, 2010, MCs]. Gyöngyösoroszi: Báránydomb déli részén, valamint Gyöngyöstarján: Bólya-puszta és Hosszú-hegy [8185.3, 2010, MCs]. Gyöngyöstarján: Bólya és Gereg-hegy [8184.4, 2010, MCs]. Nógrádkövesd: a falutól ÉNy-ra, felhagyott kaszálón [8182.1, 2008, MCs]. Szuhogy: Somod-dűlő [7590.3, 2013, MCs].

1384. Gentiana cruciata L. - Szuhogy: Somod-dűlő [7590.3, 2013, MCs].

1391. Nymphoides peltata (S.G. Gmel.) Kuntze - Hortobágy: Csécs-1,2 medencék [8492.1, 2016, KG]. Nádudvar: Nádudvari-csatorna őzesi szakasza [8592.3, 2016, KG].

1393. Vinca minor L. - Eger-Felnémet: Bajusztól É-ra [8088.3, 2010, MCs].

1395. Asclepias syriaca L. - [7984.4, 2011, MÁ]. [7693.2, 2014, MCs]. [7792.4, 2016, MCs].

1396. Vincetoxicum hirundinaria Medik. - Hortobágy: Zám, Kenderhátó-telek [8491.4, 2016, KG].

1407.2. Cuscuta epithymum (L.) Nath. subsp. kotschyi (Des Moul.) Arcang - Aggtelek: Kardos-völgy, csarabosban [7589.3, 2013, MCs]. Eger-Felnémet: Ostoros-völgy [8088.3, 2010, MCs]. Gyöngyös: Cseplye-oldal, Sár-hegy [8285.2, 2010, MCs]. Jósvafő: Szőlő-hegy [7589.1, 2013, MCs]. Novaj: Kerek-domb É-i lejtője [8188.2, 2010, MCs].

1409. Cuscuta europaea L. - Eger-Feldebrő: Galagonyás-dűlő [8088.3, 2010, MCs].

1411. Heliotropium supinum L. - Nagyhegyes: „Dézsi-láp” szikes tó [8493.4, 2016, KG].

1412. Lithospermum officinale L. - Visonta: Bajna-dűlő [8285.2, 2010, MCs].

1414. Buglossoides arvensis (L.) I.M. Johnston - Mezőkövesd: Borjú-kút [8289.2, 2014, MCs].

1434. Lycopsis arvensis L. - Hortobágy: Kónya vasúti m.h. [8493.4, 2016, KG].

1437. Anchusa officinalis L. - Törökbálint: M0 0. km mellett [8579.3, 2011, MCs].

1440. Asperugo procumbens L. - Hajdúnánás: M3 Hajdúnánási pihenőhely [8194.2, 2011, MCs]. 1446. Myosotis sylvatica (Ehrh.) Hoffm. - Gyöngyöstarján: Világos [8185.1, 2006, MCs].

1449. Myosotis sprasiflora J.G.Mikan - Bag: M3 Kisbagi pihenőhely [8382.4, 2011, MCs]. Valkó: az erdőben sokfelé [8482.2, 2006, MCs].

1450.1. Myosotis arvensis (L.) Hill. subsp. arvensis - Domaháza: taposott gyepekben sokfelé [7886.2, 2013, MCs]. Gömörszőlős: Hideg-völgy [7688.2, 2013, MCs]. Mezőkövesd: Egyház-rét [8289.2, 8289.4, 2014, MCs].

1451. Myosotis ramosissima Rochel - Gyöngyöspata: Ferge-rét [8184.4, 2008, MCs].

1467. Callitriche palustris L. - Gyöngyöspata: Havas, vizes keréknyomban [8184.4, 2008, MCs]. 1471. Ajuga Iaxmannii (L.) Benth. - Székesfehérvár: Aszal-völgy [8776.4, 2016, KGK]. 
1472. Ajuga reptans L. - [8269.3, 2016, HGy]. [8269.4, 2016, HGy]. [8270.3, 2016, HGy].

1473. Ajuga genevensis L. - [8289.4, 2014, MCs].

1477. Teucrium chamaedrys L. - Hortobágy: Juhoshát [8392.4, 2016, KG].

1479. Scutellaria hastifolia L. - Gyöngyös: Sár-hegy [8285.2, 2008, MCs]. Kelemér: Doszpoty-völgy alján lévő mocsárréten [7688.4, 2013, MCs]. Tiszadob: Horgoló [8092.2, 2014, MCs].

1485. Marrubium ×paniculatum Desr. - Hatvan: kisgombosi fás legelő [8284.3, 2009, MÁ].

1491. Galeopsis angustifolia (Ehrh.) Hoffm. - Felsőtárkány: Tiba alja [8088.3, 2010, MCs].

1492. Galeopsis pubescens Besser - Felsőtárkány: Ostoros-völgy [8088.3, 2010, MCs]. Novaj: Gyür-oldal, telepített tölgyesben [8188.2, 2010, MCs].

1494. Galeopsis tetrahit L. - Eger-Felnémet: Galagonyás-völgy [8088.3, 2010, MCs]. Sajóvelezd: Vár-hegy [7788.2, 2013, MCs].

1495. Galeopsis bifida Boenn. - Abasár: Rónya-bérc [8186.3, 2013, MCs]. Aggtelek: Kardosvölgy, csarabosban [7589.3, 2013, MCs]. Felsőtárkány: Ostoros-völgy [8088.3, 2010, MCs]. Gyöngyös: Vörösmarty-túristaház mellett és Gyöngyössolymos: a Csór-réti víztározó alatti telep betonútjának szélén [8185.2, 2013, MCs].

1497. Lamium album L. - Mezőkövesd: Borjú-kút [8289.2, 2014, MCs].

1499. Lamium amplexicaule L. - [7793.1, 2012, MCs]. [9173.3, 2016, NT]. [7688.2, 2013, MCs]. [7993.3, 2014, MCs]. [8579.3, 2011, MCs].

1500. Lamium purpureum L. - [8289.3, 2014, MCs].

1505. Leonurus marrubiastrum L. - Kisújszállás: Nagy-erdő [8790.3, 2006, MCs].

1509. Stachys recta L.- Sajókaza: Szár-hegy [7789.2, 2009, MÁ].

1510. Stachys sylvatica L. - Gödöllő: Pulyka-tető [8482.1, 2006, MCs]. Novaj: Gyűr-oldal, telepített tölgyesben [8188.2, 2010, MCs].

1511. Stachys palustris L. - Szuhafő: Petőháza [7688.2, 2009, MÁ]. Tiszalök: Lökös-dúlő [7994.4, 2014, MCs].

1513. Stachys germanica L.- Ludányhalászi: Király-hegy [7883.3, 2011, MÁ].

1517. Nepeta cataria L. - Szentistván: Salamon-major mellett a Tiszavalki-fő́csatornánál [8290.4, 2014, MCs].

1519. Glechoma hirsuta Waldst. et Kit. - Apc: Tarcod [8184.3, 2007, MCs]. Gödöllő: Pulykatető [8482.2, 2006, MCs]. Nagyréde: Cseres [8284.2, 2008, MCs].

1522. Prunella laciniata L. - Gömörszőlős: Zánkó-hegy [7688.2, 2013, MCs]. Gyöngyös: Sárhegy [8285.2, 2010, MCs]. Kelemér: Bakos-völgy oldalában [7688.3, 2009, MÁ]. Monok: Zsebrik [7792.4, 2005, MCs]. Parád: Marhád [8186.1, 2006, MCs].

1534. Origanum vulgare L. - [7689.2, 2013, MCs].

1538. Thymus glabrescens Willd. - Jánossomorja: Kerti-Bokor rétek magasabb fekvésű száraz területein [8269.3, 2016, HGy]. Rábcakapi: délies kitettségű töltésoldalakban [8269.4, 2016, HGy].

1543. Mentha pulegium L. - Gyöngyössolymos: a Csór-réti tározó és a Hidasi-erdészház közötti villanyvezeték-vízvezeték nyomvonalán [8185.2, 2004, MCs].

1549. Mentha arvensis L. - Kelemér: Doszpoty-völgy alján lévő mocsárréten [7688.4, 2013, MCs].

1556. Salvia verticillata L.- Zádorfalva: Iván-tető [7688.2, 2009, MÁ].

1562. Salvia nemorosa L. - [8480.2, 2011, MCs].

1572. Physalis alkekengi L. - Debréte: Nagy-kötél, parlagon [7491.3, 2014, MCs]. Kisújszállás: Nagy-erdő, a legnyugatabbi részeken [8790.3, 2006, MCs]. Visonta: Bajna-dúlő [8285.2, 2010, MCs].

1577. Solanum dulcamara L. - Novaj: eróziós völgyben a belterület Ny-i szélén [8188.2, 2010, MCs].

1579.2. Solanum nigrum L. subsp. schultesii (Opiz) Wessely - Gyöngyöspata: Antal-hegy [8184.3, 2006, MCs]. 
1595. Verbascum phoeniceum L. - [8185.3, 2010, MCs].

1596. Verbascum blattaria L. - [8088.3, 2010, MCs].

1597. Verbascum chaixii Vill. subsp. austriacum (Schott) Hayek - Eger-FelnémetFelsőtárkány: parlagokon és száraz-félszáraz gyepekben [8088.3, 2010, MCs]. Jósvafő: Szőlőhegy [7589.1, 2013, MCs]. Lébény: Hugati út száraz szegélyében nagy tömegben [8270.3, 2016, HGy]. Mezőkövesd: Egyház-rét [8289.2, 2014, MCs].

1599. Verbascum lychnitis L. - Gyöngyöspata: Havas, lejtősztyeppréten [8184.4, 2008, MCs]. Gyöngyöstarján: Világos [8185.1, 2006, MCs]. Sajókaza: Szár-hegy [7789.2, 2009, MÁ]. Zádorfalva: Ragyás-szőlő [7688.2, 2009, MÁ].

1602. Verbascum thapsus L.- Hatvan: kisgombosi fás legelő [8284.3, 2009, MÁ].

1604. Verbascum phlomoides L. - [7793.3, 2008, MCs].

1608. Scrophularia nodosa L. - Gömörszőlős: Szőlő-hegy [7688.2, 2009, MÁ]. Valkó: Csörszárok mellett [8482.2, 2006, MCs].

1611. Misopates orontium (L.) Raf. - Veszprém: Csap u. 3., járdarepedésben [8873.4, 2002, MVA].

1612. Microrrhinum minus (L.) Fourr. - Herend: a kerámiagyár közelében, virágágyásban [8872.3, 2016, MVA].

1614. Linaria genistifolia (L.) Mill. - Eger: Bajusz és Eger-Felnémet, Bajusztól É-ra, Tárkányi-patak melletti domb [8088.3, 2010, MCs].

1615. Linaria angustissima (Loisel.) Borbás - Visonta: Cseplye-tető [8285.2, 2010, MCs].

1616. Linaria vulgaris Mill. - [7589.1, 2013, MCs]. [7793.3, 2008, MCs].

1625. Pseudolysimchion longifolium (L.) Opiz - Eger-Felnémet: Galagonyás-dűlő [8088.3, 2010, MCs]. Nyírcsaholy: Lebuc-dűlő [8000.3, 2014, MCs].

1628. Pseudolysimachion spicatum (L.) Opiz - Sajókaza: Szár-hegy [7789.2, 2009, MÁ].

1630. Veronica scutellata L. - Jánossomorja: a Zöldházi úttól NY-ra lévő felnedvesedett tarvágáson [8269.4, 2016, HGy].

1634. Veronica catenata Pennell - Szentistván: Csincse-ér és Batúz-tanya között [8290.4, 2014, MCs].

1636. Veronica prostrata L. - Novaj: Felső-rét és Rácpa-dűlő között, erodált talajú felhagyott legelőn [8188.2, 2010, MCs]. Nyírcsaholy: Szentmiklósi-dűlő, lovasudvar [8099.4, 2014, MCs]. Rudabánya: a Kápolna- és a Nagy-hegy között, legelőn [7689.2, 2013, MCs]. Sárospatak-Végardó: Somlyód [7695.2, 2007, MCs]. Tiszadorogma: Közös legelők [8391.1, 2014, MCs].

1638. Veronica austriaca L. s. str. - Aszófő: a kempinghez vezető út padkáján [9073.3, 2007, MCs]. Bodrogkisfalud: Vár-hegy [7894.1, 2005, MCs]. Kisnána: Macskavár [8186.4, 2007, MCs]. Mád: Birsalmás-tető [7893.2, 2005, MCs].

1639. Veronica teucrium L. - Gyöngyöstarján: Káva [8184.2, 2006, MCs].

1641. Veronica chamaedrys L. s. str. - Gödöllő: Pulyka-tető [8482.1, 2006, MCs]. Mád: Birsalmás-tető [7893.2, 2005, MCs].

1642. Veronica officinalis L. - Gödöllő: Juharos-bérc [8482.2, 2006, MCs]. Mikóháza: NagyPolyán, legelőn [7595.2, 2010, MCs]. Novaj: Pipis-tető D-i lejtője, telepített tölgyesben [8188.2, 2010, MCs].

1643. Veronica montana L. - Gömörszőlős: Egerdő, gyertyános-kocsányos tölgyesben [7688.2, 2013, MCs].

1644. Veronica triphyllos L. - Nyíregyháza: M3 Nyíregyházi pihenőhely [8196.1, 2011, MCs].

1647. Veronica serpyllifolia L. - Lébény: Pintér-Hanyban egy gyengén járt földút melletti üde réten kiterjedt állományai vannak, valamint Rábcakapi: a Rábca árterében, egy kiszáradt tómeder mellett körülbelül $2 \mathrm{~m}^{2}$-es foltban [8269.4, 2015, HGy].

1648. Veronica arvensis L. - [7690.2, 2014, MCs]. [8186.4, 2007, MCs]. [7490.3, 2007, MCs]. [7992.4, 2014, MCs]. [8291.3, 2014, MCs]. 
1650. Veronica praecox All. - Bag: M3 Kisbagi pihenőhely [8382.4, 2011, MCs]. Budapest: M3 Szilas pihenőhely [8480.2, 2011, MCs]. Gelej: M3 Geleji pihenőhely [8190.4, 2011, MCs]. Hajdúnánás: M3 Hajdúnánási pihenőhely [8194.2, 2011, MCs]. Kál: M3 Rekettyés pihenőhely [8287.4, 2011, MCs]. Polgár: M3 Polgári pihenőhely [8192.4, 2011, MCs]. Szigetszentmiklós: M0 Csepeli pihenőhely [8680.1, 2011, MCs]. Törökbálint: M0 0. km mellett [8579.3, 2011, MCs]. Vecsés: M0 Alacska pihenőhely [8681.2, 2011, MCs] és Ferihegynél [8581.4, 2011, MCs].

1656. Veronica persica Poir. - Egerfarmos: a belterülettől közvetlenül D-re [8289.3, 2014, MCs].

1658. Veronica polita Fr. - Aszófő: a kempinghez vezető út padkáján [9073.3, 2007, MCs]. Budapest: M3 Szilas pihenőhely [8480.2, 2011, MCs]. Egerfarmos: a belterülettől közvetlenül D-re [8289.3, 2014, MCs]. Mezőkövesd: Egyház-rét és Borjú-kút [8289.2, 2014, MCs] és Kánya-patak menti gyepekben [8289.4, 2014, MCs].

1660. Melampyrum cristatum L. - Gyöngyös: Cseplye-oldal, Sár-hegy [8285.2, 2010, MCs].

1661. Melampyrum arvense L. - Sárospatak-Végardó: Somlyód [7695.2, 2007, MCs]. Zádorfalva: Nagy-Szőlő-tető, cseres-tölgyesben [7588.4, 2014, MCs].

1662. Melampyrum barbatum Waldst. et Kit. - Rózsaszentmárton: Tarcodi-pincék felett, törpemandulásban [8184.3, 2007, MCs].

1668. Euphrasia stricta Wolf - Abod: Fazekas-tetőtől DNy-ra [7690.2, 2014, MCs]. EgerFelnémet: Ostoros-völgy és Tó-lápa [8088.3, 2010, MCs]. Gyöngyös: Cseplye-oldal és Visontai-hegy oldala [8285.2, 2010, MCs]. Novaj: a belterülettől É-ra, gyepekben és parlagokon [8188.2, 2010, MCs].

1669. Euphrasia tatarica Fisch. - Gyöngyöstarján: Bólya-tető [8184.4, 2010, MCs] és Merőkő-völgy [8185.3, 2010, MCs].

1671. Odontites vernus (Bellardi) Dumort. - Felsőtárkány: Tiba alja-dűlő [8088.3, 2010, MCs]. Mikóháza: Nagy-Polyán [7595.2, 2010, MCs]. Novaj: a belterülettől É-ra parlagokon és szárazgyepekben [8188.2, 2010, MCs]. Szuhogy: Somod-dűlő [7590.3, 2013, MCs].

1703. Orobanche lutea Baumg. - Tállya: Patócs-hegy [7793.3, 2008, MCs].

1718. Asperula cynanchica L. S. str. - [7695.2, 2007, MCs].

1723. Galium boreale L. - Tiszalök: Lökös-dűlő [7994.4, 2014, MCs].

1724. Galium rubioides L. - Jánossomorja: Korona erdő É- oldalában az állomány szélében pár tövet számláló állománya található meg [8269.3, 2015, HGy].

1726. Galium odoratum (L.) Scop. - Valkó: Erzsébet-pihenő mellett és Szent Pál-hegy [8482.2, 2006, MCs].

1728. Galium glaucum L. - Novaj: a belterülettől É-ra, a Novaji-patak K-i oldalán, meredek lejtőn [8188.2, 2010, MCs]. Szerencs: Aranka-tető [7893.1, 2005, MCs]. Tarnaszentmária: Vár-hegy [8187.1, 2005, MCs]. Tállya: Patócs-hegy [7793.3, 2005, MCs].

1729. Galium palustre L. - [8299.1, 2014, MCs]. [7688.4, 2013, MCs]. [8290.4, 2014, MCs].

1742. Galium schultesii Vest - Sajóvámos: Rednek-erdő, a Frank-hegy csúcsa mellett [7791.3, 2012, MCs].

1743. Galium abaujense Borbás - Aggtelek: Szőlőhegy [7589.1, 2013, MCs]. Dubicsány: Gyöngyös-hegy [7788.2, 2013, MCs]. Eger-Felnémet: cserjésekben, erdőkben és Felsőtárkány: Ostoros-völgy [8088.3, 2010, MCs]. Gyöngyös: Sár-hegy [8285.2, 2010, MCs]. Gyöngyöspata: Antal-hegy [8184.3, 2006, MCs]. Gyöngyössolymos-Parádsasvár: Csór-hegy környéki erdőkben [8185.2, 2004, MCs]. Parád: Som-hegy [8186.1, 2006, MCs]. Pásztó: Széles-bükk és Gombás-oldal [8084.4, 2006, MCs].

1747. Cruciata pedemontana (Bellardi) Ehrend. - Gyöngyöstarján: Hosszú-hegy [8185.3, 2010, MCs]. Tiszadob: Ó-Kenéz [7993.3, 2014, MCs]. Tiszadorogma: Közös legelők [8291.3, 8391.1, 2014, MCs].

1748. Cruciata laevipes Opiz - Gyöngyöspata: Ferge-rét [8184.4, 2008, MCs].

1753. Plantago tenuiflora Waldst. et Kit. - Szentistván: Salamon-major mellett [8290.4, 2014, MCs]. 
1754. Plantago schwarzenbergiana Schur - Konyár: Békarívás [8695.4, 1994, KG]. Kismarja: Marjai-legelő [8796.4, 1994, KG]. Mezőkövesd: Egyház-rét [8289.2, 8289.4, 2014, MCs]. Tiszavalk: Urak legelője [8390.2, 2014, MCs].

1764. Viburnum opulus L. - [8088.3, 2010, MCs].

1782. Valeriana dioica L. - Lébény: Tárnokréti-Hany, Pintér-Hany, Fűzfaszigeteki rétek középső területén, láp-mocsárréteken több helyen is előfordul [8269.4, 8269.2, 2016, HGy]. Újrónafő: Krisztina-berek [8269.2, 2016, HGy].

1787. Dipsacus fullonum L. - Lébény: száraz rétek, útrézsűk gyakori faja [8269.2, 8270.1, 8270.3, 2015, HGy].

1801. Campanula bononiensis L. - Nagytarcsa: Küdői-hegy [8481.4, 2006, MCs].

1802. Campanula rapunculoides L. - Eger-Felnémet: Bajusztól É-ra, Eged alja és Galagonyás-dűlő [8088.3, 2010, MCs]. Hidasnémeti: Keserű-völgy [7493.3, 2006, MCs].

1804. Campanula trachelium L. - Hidasnémeti: Keserü-völgy [7492.4, 2006, MCs].

1805. Campanula persicifolia L. - [8284.1, 2007, MCs].

1807. Campanula patula L. - Eger-Felnémet: Ostoros-völgy [8088.3, 2010, MCs]. Gyöngyössolymos: a Csór-réti tározó és a Hidasi-erdészház közötti villanyvezetékvízvezeték nyomvonalán [8185.2, 2004, MCs]. Jánossomorja: Kerti-Bokor rétek magasabb fekvésű részein száraz kaszálókon, szórványos előfordulású [8269.3, 2016, HGy]. Lébény: Ottó-major [8269.2, 2016, HGy].

1816. Jasione montana L. - Nyírcsaholy: Szentmiklósi-dűlő, lovasudvar [8099.4, 2014, MCs].

1821. Solidago virgaurea L. - Novaj: a belterülettől É-ra parlagokon és szárazgyepekben [8188.2, 2010, MCs].

1824. Solidago canadensis L. - [7491.3, 2014, MCs]. [7689.2, 2013, MCs].

1828. Aster linosyris (L.) Bernh. - Jósvafő: Szőlő-hegy [7589.1, 2013, MCs]. Tiszafüred: Kosárhát, Beke-halomtól nyugatra gyepen [8491.3, 2006, KGK].

1829.1. Aster sedifolius L. s. str. - Tiszadob: Ó-Kenéz [7993.3, 2014, MCs].

1838.2. Erigeron annuus (L.) Pers. subsp. annuus - [8185.3, 2010, MCs].

1839. Erigeron acris L. - Tállya: Patócs-hegy [7793.3, 2008, MCs].

1841. Filago lutescens L. - Gyöngyöstarján: Bólya, szántóparlagon [8185.3, 2010, MCs].

1843. Filago arvensis L. - Gyöngyös-Visonta: Sár-hegy [8285.2, 2010, MCs]. Hortobágy: Kondás [8392.4, 2016, KG]. Kunmadaras: Redemptus [8591.3, 2016, KG].

1844. Filago minima (Sm.) Pers. - Bátorliget: Bátori- és Cserepesi-legelő [8299.1, 2014, MCs]. 1848. Gnaphalium luteoalbum L. - Gyöngyöstarján: Bólya, felhagyott szántón és szántott aljú gyümölcsösben [8185.3, 2010, MCs].

1851. Inula helenium L. - Debréte: Nagy-kötél, parlagon [7491.3, 2014, MCs].

1852. Inula conyza DC. - Novaj: Méti-hegy, parlagon [8188.2, 2010, MCs].

1854. Inula britannica L. - [8285.2, 2010, MCs]. [7994.4, 2014, MCs].

1857.2. Inula salicina L. subsp. aspera (Poir.) Hayek - Jósvafő: Szőlő-hegy [7589.1, 2013, MCs].

1867. Bidens tripartita L. - [7994.4, 2014, MCs].

1879. Xanthium strumarium L. - [8285.2, 2010, MCs].

1885. Galinsoga ciliata (Raf.) S.F. Blake - Debrecen: Egyetem tér [8495.2, 2016, MVA]. Veszprém: Állatkert [8973.1, 2016, MVA].

1892. Anthemis ruthenica L. - Budapest: M3 Szilas pihenőhely [8480.2, 2011, MCs].

1893. Anhemis austriaca Jacq. - Ecséd: M3 Ecsédi pihenőhely [8284.4, 2011, MCs]. Tállya: Patócs-hegy [7793.3, 2008, MCs].

1894. Anthemis tinctoria L. - Kisnána: Macskavár [8186.4, 2007, MCs]. Tállya: Patócs-hegy [7793.3, 2008, MCs].

1897. Achillea crithmifolia Waldst. et Kit. - Abasár-Gyöngyös-Visonta: Sár-hegy [8285.2, 2010, MCs]. 
1899. Achillea nobilis L. - Jósvafő: Szőlő-hegy [7589.1, 2013, MCs]. Szögliget: Szádvár oldalában [7489.4, 7490.3, 2007, MCs].

1903. Achillea setacea Waldst. et Kit. - Mezőkövesd: Egyház-rét [8289.4, 2014, MCs].

1904. Achillea asplenifolia Vent. - Besenyőtelek: Csincsa-csatorna menti kaszálón [8388.2, 2008, MCs]. Jánossomorja: Kerti-Bokor nevű réteken Korona-erdőtől ÉNy-ra, ritka [8269.3, 2015, HGy]. Lébény: Fűzfaszigeteki mocsárrétek mély fekvésű rétjein fordul elő szálanként [8269.2, 2016, HGy]. Tiszadorogma: Közös legelők [8291.3, 8391.1, 2014, MCs].

1905. Achillea pannonica Scheele - Gyöngyöstarján: Gereg-hegy és környéke [8184.4, 8185.3, 2010, MCs].

1910. Tripleurospermum perforatum (Mérat) M.Lainz - [8088.3, 2010, MCs]. [8289.2, 2014, MCs]. [8188.2, 2010, MCs]. [8290.4, 2014, MCs].

1911. Matricaria recutita L. - Rábcakapi: szántók szegélyében, lakott területek mellett gyomtársulásokban is [8269.4, 2014, HGy]. Székesfehérvár: Új-gáti-parrag szikes foltjai [8877.1, 2011, KGK].

1912. Matricaria discoidea DC. - Egerlövő: Tilaj és Mezőkövesd, Egyház-rét [8289.4, 2014, MCs]. Kesznyéten: Szamár-háttól D-re, vetett gyepben [8092.1, 2014, MCs]. Mezőkövesd: Egyház-rét és Borjú-kút [8289.2, 2014, MCs]. Szentistván: Salamon-major mellett [8290.4, 2014, MCs].

1916. Leucanthemella serotina (L.) Tzvelev - Tiszadorogma: Keszeges és Nagy-vájás között, mocsárréten [8291.3, 2014, MCs].

1922. Artemisia annua L. - Hortobágy: 11-es halastómedence és Kungyörgy között [8392.4, 2016, KG].

1923. Artemisia santonicum L. - Mezőzombor: Fecskés [7893.3, 2004, MCs].

1929. Artemisia pontica L. - Tiszadob: Ó-Kenéz [7993.3, 2014, MCs]. Tiszalök: Lökös-dúlő [7994.4, 2014, MCs].

1938. Erechtites hieraciifolia (L.) Raf. ex DC. - Aggtelek: Kardos-völgy, csarabosban [7589.3, 2013, MCs].

1941. Tephroseris integrifolia (L.) Holub - Monok: Zsebrik [7792.4, 2005, MCs].

1943. Senecio vulgaris L. - [9173.3, 2016, NT]. [8185.3, 2010, MCs].

1946. Senecio vernalis Waldst. et Kit. - Lébény: Nagy-dombon találtam meg magas tőszámú állományát, 200-300 tő [8270.1, 2016, HGy]. Rábcakapi: szálanként jelenik meg a száraz töltésoldalakban [8269.4, 2016, HGy]. Vecsés: M0 autópálya mellett, Ferihegynél [8581.4, 2011, MCs].

1948. Senecio erucifolius L. - Lébény: Ottó-major, vad által erősen bolygatott réteken szórtan fordul elő [8269.2, 2016, HGy]. Szólád: Köpü-Horog [9173.3, 2016, NT]. Tállya: Patócs-hegy [7793.3, 2008, MCs].

1949. Senecio jacobaea L. - Tiszadob: Horgoló [8092.2, 2014, MCs].

1951. Senecio erraticus Bertol. - Gyöngyös: Sár-hegy [8285.2, 2008, MCs]. Szentistván: Salamon-major mellett a Tiszavalki-főcsatornánál [8290.4, 2014, MCs]. Tiszavalk: Tetesfenék, vetett gyepben [8390.2, 2014, MCs].

1957. Senecio doria L. - Monok: Hosszú-völgy és Oláh-völgy [7792.4, 2016, MCs].

1963. Xeranthemum cylindraceum Sibth. et Sm. - Visonta: Sár-hegy és Bajna-dűlő [8285.2, 2010, MCs].

1965. Echinops sphaerocephalus L. - Rábcakapi: Rábca hullámterében nyílt nemesnyáras szegélyében egy helyen találtam 30-40 tövet számláló állományát [8269.4, 2014, HGy]. Tállya: Patócs-hegy [7793.3, 2008, MCs].

1968. Arctium lappa L. - [8188.2, 2010, MCs].

1973. Carduus nutans L. - [8285.2, 2008, MCs]. [8290.4, 2014, MCs].

1974. Carduus acanthoides L. - [8495.4, 2004, MCs]. 
1978. Carduus collinus Waldst. et Kit. - Gyöngyöstarján: Öreg-hegy és Diós között [8185.3, 2010, MCs].

1979. Cirsium vulgare (Savi) Ten. - [8088.3, 2010, MCs]. [8188.2, 2010, MCs].

1980. Cirsium eriophorum (L.) Scop. - Gyöngyöstarján: Bólya-tető [8184.4, 2010, MCs]

1984. Cirsium brachycephalum Jur. - Lovasberény: Alsó-rét déli felének mocsárrétjei [8777.1, 2015, KGK].

1987. Cirsium pannonicum (L. f.) Link - Gyöngyös: Visontai-hegy és Visonta, Sár-hegy [8285.2, 2010, MCs].

1993. Serratula tinctoria L. - Tiszalök: Lökös-dűlő [7994.4, 2014, MCs].

1999.3. Centaurea jacea L. subsp. angustifolia Gremli - Jósvafő: Szőlő-hegy [7589.1, 2013, MCs].

2000. Centaurea indurata Janka - Eger-Felnémet: Ostoros-völgy és Galagonyás-dűlő [8088.3, 2010, MCs].

2003. Centaurea cyanus L. - Kánya: Tab felé, vetés szélén [9274.3, 2016, NT]. Nagycsepely: Pácsmánd [9272.4, 2016, NT].

2005. Centaurea triumfettii All. - Jósvafő: Szőlő-hegy és Gerge-bérc [7589.1, 2013, MCs].

2008.2. Centaurea scabiosa L. subsp. spinulosa (Rochel) Arcang. - Jósvafő: Szőlő-hegy [7589.1, 2013, MCs]. Monok: Hosszú-völgy és Oláh-völgy [7792.4, 2016, MCs].

2010. Centaurea stoebe L. - Eger-Szarvaskő: Vár sánca melletti kis tisztáson [8087.2, 2007, MCs]. Verőce: Lőcs-oldal [8180.3, 2007, MCs].

2017. Hypochoeris radicata L. - Nyírcsaholy: Szentmiklósi-dűlő, lovasudvar [8099.4, 2014, MCs].

2020. Leontodon autumnalis L. - Gyöngyöspata: Ferge-rét [8184.4, 2008, MCs]. Lébény: Farkas-domb, Viperás domb [8270.3, 8269.4, 2016, HGy]. Mikóháza: Nagy-Polyán [7595.2, 2010, MCs]. Novaj: a belterülettől É-ra parlagokon és gyepekben [8188.2, 2010, MCs]. Rábcakapi: félszáraz, üde réteken erőszegélyekben, kaszálókon [8269.4, 2016, HGy].

2021. Leontodon hispidus L. - [8182.1, 2008, MCs].

2023. Picris hieracioides L. - [8196.1, 2011, MCs]. [8192.4, 2011, MCs].

2024. Podospermum canum (C.A.Mey.) Griseb - Aszófő: a kempinghez vezető út padkáján [9073.3, 2007, MCs]. Mezőzombor: Fecskés [7893.3, 2004, MCs]. Törökbálint: M0 0. km mellett [8579.3, 2011, MCs].

2032. Tragopogon dubius Scop. - [7886.2, 2013, MCs].

2033. Tragopogon orientalis L. - [8190.4, 2011, MCs]. [7688.2, 2013, MCs].

2035. Sonchus asper (L.) Hill - [8285.2, 2010, MCs]. [8184.4, 2010, MCs]. [8188.2, 2010, MCs].

2036. Sonchus oleraceus L. - [8088.3, 2010, MCs]. [8285.2, 2010, MCs].

2042. Lactuca saligna L. - Gyöngyöstarján: Bólya, fiatal szántóparlagon [8184.4, 2010, MCs] és Bólya-puszta, felhagyott, egykor szántott aljú gyümölcsös [8185.3, 2010, MCs]. Novaj: Herman-tető és Méti-hegy, parlagokon [8188.2, 2010, MCs]. Sajóvámos: Fenyves-tető [7791.3, 2013, MCs].

2043. Lactuca serriola L. - [8284.4, 2011, MCs]. [8088.3, 2010, MCs]. [7792.4, 2005, MCs]. [8188.2, 2010, MCs]. [8290.4, 2014, MCs].

2046. Mycelis muralis (L.) Dumort. - [8188.2, 2010, MCs].

2047. Taraxacum bessarabicum (Hornem.) Hand.-Mazz. - Debrecen: Tócóvölgy vasútállomástól É-ra, legelőn [8495.4, 2004, MCs]. Mezőzombor: Fecskés [7893.3, 2004, MCs]. Rudabánya: meddőhányón, lókarámban, a Kápolna-hegy mellett [7689.2, 2013, MCs].

2051. Taraxacum palustre agg. - Lébény: az Urhanya-csatorna és a bormászpusztai út kereszteződésétől ÉNy-i irányban elhelyezkedő félnedves réten (25-30 tő), illetve a Füzfaszigeteki rétek déli szélében 10-15 tő [8270.3, 8269.2, 2016, HGy].

2052. Chondrilla juncea L. - Hortobágy: Kónya vasúti m.h. [8493.4, 2016, KG]. Lébény: Farkas-dombon, ezen felül száraz délies töltésoldalakon nem gyakori [8270.3, 2016, HGy]. Nagyiván: Tiszaörsre vezető út és a második dűlő találkozása [8591.1, 2016, KG].

2053. Lapsana communis L. - Kisújszállás: Nagy-erdő [8790.3, 2006, MCs]. 
2054. Crepis rhoeadifolia M. Bieb. - Nyírcsaholy: Szentmiklósi-dűlő, lovasudvar [8099.4, 2014, MCs]. Tállya: Patócs-hegy [7793.3, 2008, MCs].

2056. Crepis setosa Haller - Ecséd: M3 Ecsédi pihenőhely [8284.4, 2011, MCs]. Gelej: M3 Geleji pihenőhely [8190.4, 2011, MCs]. Gyöngyöstarján: Bólya, parlagon [8184.4, 2010, MCs]. Novaj: a belterülettől ÉK-re, egykor szántott aljú, a közelmúltban felhagyott gyümölcsösben [8188.2, 2010, MCs]. Tiszabábolna: Orosz-ér és Tiszavalki-főcsatorna között [8290.4, 2014, MCs]. Zádorfalva: Pót-haraszt, parlagon [7688.2, 2013, MCs].

2059. Crepis pulchra L. - Tállya: Patócs-hegy [7793.3, 2008, MCs].

2062. Crepis biennis L. - Lébény: Üde-nedves réteken, de útszéleken is [8269.2, 8269.4, 8270.1, 8270.3, 2016, HGy]. Monok: Zsebrik [7792.4, 2005, MCs]. Rábcakapi: árterek, töltésrézsűk [8269.4, 2016, HGy]. Tárnokréti: árterek, hullámterek [8269.4, 8269.4, 2016, HGy]. Újrónafő: Krisztina-berek [8269.2, 2016, HGy].

2073. Hieracium bauhinii Schult ex Besser. - Aggtelek: Kardos-völgy, csarabosban [7589.3, 2013, MCs]. Jósvafő: Szőlő-hegy [7589.1, 2013, MCs]. Monok: Zsebrik [7792.4, 2005, MCs]. Tállya: Palota-hegy [7793.3, 2005, MCs].

2081. Hieracium umbellatum L. - Gyöngyös: Sár-hegy [8285.2, 2008, MCs]. Szerencs: Aranka-tető [7893.1, 2005, MCs]. Tállya: Patócs- és Palota-hegy [7793.3, 2005, MCs].

2082. Hieracium sabaudum L. - Gömörszőlős: Zánkó-hegy [7688.2, 2013, MCs].

2123. Alisma gramineum Lej. - Fegyvernek: Kenderes felé, a 4-es út mentén, belvizes szántón [8789.4, 2016, MVA].

2141. Veratrum album L. - Told: legelő [8895.4, 1989, KG].

2144. Anthericum ramosum L. - Orgovány: Nagy-Siványtól É-ra, Kontra-tanya közelében, homoki borókás-nyárasban [9283.3, 2013, MCs].

2155. Ornithogalum brevistylum Wolfner - Karcag: Tetveshát (Németéri-főcsatorna mellett) [8592.3, 2016, KG].

2168. Muscari comosum (L.) Mill. - Aggtelek: Kardos-völgy, csarabosban [7589.3, 2013, MCs]. Jósvafő: Szőlő-hegy [7589.1, 2013, MCs].

2169. Muscari neglectum Guss. ex Ten. - Nagyiván: Vitéz-erdő [8491.4, 2016, KG].

2171. Allium vineale L. - [8299.1, 2014, MCs]. [8269.4, 2016, HGy].

2172. Allium sphaerocephalon L. - Bodrogkisfalud: Vár-hegy [7894.1, 2005, MCs].

2174. Allium scorodoprasum L. s. str. - Besenyőtelek: Tepély-puszta [8389.1, 2008, MCs].

2175.2. Allium rotundum L. subsp. waldsteinii (G.Don) Stearn - Tállya: Patócs-hegy [7793.3, 2008, MCs].

2182. Allium ursinum L. - Jánossomorja: Gulyaállási út mentén lévő keményfaligetekben, fasorokban, illetve kökényesek alatt [8269.3, 2016, HGy]. Székesfehérvár: Máriamajorierdő északi része [8776.2, 2013, KGK].

2187. Allium lusitanicum Lam. - Gyöngyös: Cseplye-oldal [8285.2, 2010, MCs].

2195. Polygonatum latifolium (Jacq.) Desf. - Gyöngyös: Sár-hegy és Visonta, Bajna-dűlő [8285.2, 2010, MCs].

2196. Polygonatum odoratum (Mill.) Druce - Jánossomorja: Korona erdőben állomány alatt, illetve az állomány szélében is előfordul [8269.3, 2016, HGy].

2228. Gagea bohemica (Zauschn.) Schult. et Schult. f. - Pátka: Királyberek [8777.1, 2016, KGK].

2229. Gagea szovitsii (Láng) Besser - Tiszafüred: Demeháza [8491.3, 2016, KG]. Hajdúszoboszló: Angyalháza, Kostelek [8493.3, 2016, KG].

2241. Galanthus nivalis L. - Pátka: Páskom, kicsinyke erdőmaradvány [8776.2, 2016, KGK].

2247. Eichhornia crassipes (Mart.) Solms - Székesfehérvár: Rácbányai kis tó [8876.2, 2015, KGK].

2253. Iris spuria L. - Lovasberény: Büdös-tó melletti patakvölgyi rét [8677.3, 2015, KGK].

Tiszadob: Ó-Kenéz [7993.3, 2014, MCs].

2256. Iris pumila L. - Pátka: Királyberek [8777.1, 2016, KGK].

2261. Crocus reticulatus Steven - Aba: Felsőszentiván, Sóstó partja [8976.2, 2015, KGK]. 
2267. Gladiolus palustris Gaudin - Nyirád: Sár-álló [8970.3, 2016, MVA, Vidéki Róbert].

2270. Juncus effusus L. - [8269.4, 2015, HGy].

2271. Juncus conglomeratus L. - Mikóháza: Nagy-Polyán [7595.2, 2010, MCs].

2276. Juncus tenuis Willd. - Gyöngyös: Visontai-hegy [8285.2, 2010, MCs]. Gyöngyöstarján:

Bólya-tető mellett, földúton [8184.4, 2010, MCs]. Mezőkövesd: Egyház-rét [8289.2, 2014, MCs]. Mikóháza: Nagy-Polyán [7595.2, 2010, MCs]. Szentistván: Salamon-major mellett a Tiszavalki-főcsatornánál, lucernaparlagon [8290.4, 2014, MCs]. Tiszavalk: Tetes-fenék, vetett gyepben [8390.2, 2014, MCs].

2278. Juncus gerardii Loisel. - Mezőkövesd: Egyház-rét [8289.4, 2014, MCs]. Mezőzombor: Fecskés [7893.1, 7893.3, 2004, MCs]. Szentistván: Salamon-major mellett [8290.4, 2014, MCs].

2284. Juncus articulatus L. - Jánossomorja: Kerti-Bokor [8269.3, 2016, HGy]. Lébény: Polgári-Pintér Hany, Fűzfaszigetek, Urhanyi rétek, Pintér-Hany, belvizes foltokban [8269.4, 8270.1, 8270.3, 2016, HGy]. Újrónafő: Krisztina-berek [8269.2, 2016, HGy].

2287. Luzula luzuloides (Lam.) Dandy et Wilmott - Felsőtárkány: Ostoros-völgy [8088.3, 2010, MCs].

2289. Luzula campestris (L.) DC. s. str. - Gyöngyös: Cseplye-oldal és Visonai-hegy oldala [8285.2, 2010, MCs].

2294. Festuca altissima All. - Gyöngyöspata: Havas, elcseresített gyertyános-tölgyesben [8184.4, 2008, MCs].

2296. Festuca gigantea (L) Vill. - Abasár: Rónya-bérc [8186.3, 2013, MCs].

2297. Festuca arundinacea Schreb. - Kelemér: Doszpoty-völgy alján lévő mocsárréten [7688.4, 2013, MCs].

2298. Festuca pratensis Huds. - [7589.1, 2013, MCs]. [7595.2, 2009, MCs]. [7595.4, 2009, MCs]. [8290.4, 2014, MCs].

2299. Festuca heterophylla Lam. - Abasár: Rónya-bérc [8186.3, 2013, MCs]. Gyöngyöspata: Havas [8184.4, 2008, MCs].

2301. Festuca rubra L. - Gyöngyösoroszi: Bárány-domb déli részén [8185.3, 2006, MCs]. Gyöngyöspata: Ferge-rét [8184.4, 2008, MCs]. Pécel: Vár-hegy [8482.3, 2006, MCs].

2314. Festuca pseudodalmatica Krajina ex Domin - Gyöngyöspata: Havas, lejtősztyeppréten [8184.4, 2008, MCs].

2316. Festuca pseudovina Hackel - [7886.2, 2013, MCs]. [7993.3, 2014, MCs].

2317. Lolium perenne L. - [8290.4, 2014, MCs].

2322. Vulpia myuros (L.) C.C.Gmel. - Hortobágy: Czinege J u. 12. árokpart [8492.2, 2016, KG]. Nádudvar: Borzas, Nagy-sziget [8592.2, 1981, KG] és a Bökönyi-tanya helye [8592.1, 2014, KG]. Nyírcsaholy: Szentmiklósi-dűlő, lovasudvar [8099.4, 2014, MCs]. Szigetszentmiklós: M0 Csepeli pihenőhely [8680.1, 2011, MCs].

2327. Poa compressa L. - Bátorliget: Bátori- és Cserepesi-legelő [8299.1, 2014, MCs]. Gyöngyöspata: Gereg [8184.4, 2010, MCs]. Hajdúnánás: M3 Hajdúnánási pihenőhely [8194.2, 2011, MCs]. Kesznyéten: Szamár-háttól D-re, vetett gyepben [8092.1, 2014, MCs].

2333. Poa nemoralis L. - Gyöngyöspata-Gyöngyöstarján: Gereg [8184.4, 2006, MCs]. Jánossomorja: Korona erdőben, az erdőállomány alatt, illetve erdőszélen is [8269.3, 2016, HGy]. Lébény: keményfás ligetekben (hajófordulói liget), Lébényi tölgyerdő [8269.4, 8270.3, 2015, HGy].

2337. Poa angustifolia L. - [8480.2, 2011, MCs].

2338. Puccinellia distans (Jacq.) Parl. - [8290.4, 2014, MCs].

2343. Dactylis polygama Hor. - Hatvan-Kisgombos: Legelőerdő, bozótban [8284.3, 2007, MCs]. Kisnána: Hosszú-hegy lába [8186.2, 2007, MCs]. Nagytarcsa: Küdői-hegy [8481.4, 2006, MCs]. Pásztó: Város-erdő, Kerek-domb [8184.1, 2007, MCs].

2347. Apera spica-venti (L.) Beauv. - Eger-Felnémet: Galagonyás-dúlő [8088.3, 2010, MCs]. Nyírcsaholy: Szentmiklósi-dűlő, lovasudvar [8099.4, 2014, MCs]. 
2356. Melica transsilvanica Schur - Gyöngyöstarján: Világos [8185.1, 2006, MCs].

2357. Melica altissima L. - Visonta: Bajna-dűlol [8285.2, 2010, MCs].

2358. Melica uniflora L. - Gyöngyös: Sár-hegy és Visonta, Bajna-dűlő [8285.2, 2010, MCs].

Mikóháza: Nagy-Polyán, gyertyános-kocsányos tölgyesben [7595.2, 2011, MCs].

2360. Melica picta K.Koch - Gyöngyös: Felső-eke feletti erdôs sövény [8285.2, 2010, MCs].

2361. Glyceria maxima (Hartm.) Holmb. - Tiszalök: Lökös-dűlő [7994.4, 2014, MCs].

2363. Glyceria fluitans (L.) R.Br. - Szentistván: Csincse-ér és Batúz-tanya között [8290.4, 2014, MCs].

2370. Bromus hordeaceus L. - [8388.2, 2008, MCs]. [8480.2, 2011, MCs]. [7886.2, 2013, MCs]. [8289.3, 2014, MCs]. [8088.3, 2010, MCs]. [8190.4, 2011, MCs]. [8194.2, 2011, MCs]. [8192.4, 2011, MCs]. [7689.2, 2013, MCs]. [8680.1, 2011, MCs]. [8579.3, 2011, MCs].

2374. Bromus squarrosus L. - Abaújszántó: Sátor-hegy alatt, szőlősorközben [7793.1, 2012, MCs]. Novaj: a településtől É-ra, parlagokon többfelé [8188.2, 2010, MCs].

2375. Bromus arvensis L. - [8388.2, 2008, MCs]. [8288.4, 2008, MCs]. [8389.3, 2008, MCs]. [8389.1, 2008, MCs]. [8285.2, 2008, MCs]. [8188.2, 2010, MCs]. [8389.2, 2008, MCs]. [8285.2, 2010, MCs].

2376. Bromus japonicus Thunb. - Lébény: Ottó-major, Hugati út rézsűjében, száraz bolygatott helyeken [8269.2, 2016, HGy].

2378. Bromus commutatus Schrad. - Szentistván: Salamon-major mellett a Tiszavalkifő́csatornánál, valamint Tiszabábolna, Orosz-ér és Tiszavalki-fő́csatorna között [8290.4, 2014, MCs].

2379. Bromus inermis Leyss. - [7893.2, 2005, MCs]. [8290.4, 2014, MCs].

2380. Bromus erectus Huds. - Tornanádaska: Temető-dúlő, kaszált parlagon [7490.2, 2014, MCs].

2383. Bromus ramosus Huds. s. str. - Dubicsány: Gyöngyös-hegy [7788.2, 2013, MCs].

2388. Bromus tectorum L. - [8284.4, 2011, MCs]. [8188.2, 2010, MCs]. [8680.1, 2011, MCs]. [8579.3, 2011, MCs].

2393. Elymus caninus (L.) L. - Aldebrő: Cseralja, rontott keményfaligeterdőben [8187.3, 2007, MCs].

2396. Elymus hispidus (Opiz) Melderis - Hort: Cseplye [8284.4, 2008, MCs]. Jánossomorja: Vörös csillag-major közelében, földút melletti száraz gyepben [8269.3, 2016, HGy].

2398. Aegilops cylindrica Host - Nagyiván: dűlőutak [8491.4, 2016, KG]. Karcag: Ecsehalom [8591.4, 2016, KG].

2405. Hordeum jubatum L. - Hortobágy: Malomháza [8492.4, 2016, KG] és Máta [8492.2, 2016, KG]. Nyáregyháza: 405-ös út és a Nyáregyháza és Újlengyel közötti út találkozása [8782.4, 2013, KGK].

2410. Hordeum hystrix Roth - Szentistván: Szék lápa mellett [8290.4, 2014, MCs].

2418. Avena fatua L. - Besenyőtelek: Alsó-részi-ér, ugaron [8389.3, 2008, MCs]. Gyöngyös: Sár-hegy [8285.2, 2008, MCs].

2426. Ventenata dubia (Leers) Coss. - Besenyőtelek-Mezőtárkány: Csincsa-csatorna mellett [8388.2, 2008, MCs].

2430. Koeleria cristata (L.) Pers. em. Borbás ex Domin s. str. - Tiszadorogma: Közös legelők [8291.3, 2014, MCs].

2434. Trisetum flavescens (L.) Beauv. - Herend: bányató partján levő mezofil gyepben [8872.3, 2016, MVA]. Jósvafő: Gerge-bérc [7589.1, 2014, MCs].

2435. Deschampsia caespitosa (L.) Beauv. - Gyöngyösoroszi: Bárány-domb déli részén [8185.3, 2006, MCs]. Mezőkövesd: Egyház-rétre járó dűlő [8289.2, 2014, MCs]. Mikóháza: Nagy-Polyán [7595.2, 2010, MCs].

2441. Anthoxanthum odoratum L. - Lébény: a belső Fűzfaszigeteki rétek alacsony növényzetű részein foltokban megjelenik [8270.1, 2016, HGy]. 
2445. Corynephorus canescens (L.) Beauv. - Nyírcsaholy: Szentmiklósi-dűlő, lovasudvar [8099.4, 2014, MCs].

2446. Agrostis capillaris L. - Domaháza: mészkerülő gyepekben sokfelé [7886.2, 2013, MCs]. Gömörszőlős: Zánkó-hegy [7688.2, 2013, MCs]. Gyöngyöspata: Ferge-rét [8184.4, 2008, MCs]. Mikóháza: Nagy-Polyán, legelőn [7595.2, 2009, MCs].

2452. Calamagrostis arundinacea (L.) Roth - Felsőtárkány: Ostoros-völgy [8088.3, 2010, MCs]. 2465. Alopecurus geniculatus L. - Besenyőtelek: Alsó-részi-ér, ugaron [8389.3, 2008, MCs].

2466. Alopecurus aequalis Sobol. - Szentistván: Salamon-major mellett a Tiszavalkifócsatornánál [8290.4, 2014, MCs].

2477. Stipa pennata L. - Lébény: Farkas-dombon van egy körülbelül 100 tövet számláló állománya, illetve a Viperás domb déli szélében van egy kisebb kiterjedésủ állománya, 25-30 tő [8270.3, 8269.4, 2016, HGy]. Székesfehérvár: Borszéki út menti löszgyep [8876.1, 2016, KGK].

2469. Phalaris arundinacea L. - [8000.3, 2014, MCs].

2483. Danthonia decumbens (L.) DC. - Mikóháza: Nagy-Polyán [7595.2, 2010, MCs].

2484-2485. Molinia caerulea agg. - Monok: Nagy-tábla, szántók közötti földút mezsgyéjén [7792.4, 2016, MCs].

2486. Nardus stricta L. - Aggtelek: Kardos-völgy, csarabosban [7589.3, 2013, MCs].

2488. Eragrostis minor Host - [8285.2, 2010, MCs]. [8188.2, 2010, MCs].

2490. Eragrostis pilosa (L.) Beauv. - Vámosúffalu: Olaszliszka-Tolcsva vasútállomás [7794.2, 2016, MCs].

2494. Crypsis aculeata (L.) Aiton - Nagyiván: Labodás [8491.4, 2016, KG]. Kunmadaras: Csonka-Csukás-zug [8591.2, 1980, KG] és Róna-fenék [8591.4, 2016, KG].

2496. Crypsis alopecuroides (Piller et Mitterp.) Schrad. - Szentistván: Salamon-major mellett [8290.4, 2014, MCs].

2498. Cynodon dactylon (L.) Pers. - [7793.1, 2012, MCs]. [8188.2, 2010, MCs].

2499. Tragus racemosus (L.) All. - Ártánd: határátkelőhely, csak 3-4 tő [8896.4, 2016, MCs].

2507. Echinochloa crus-galli (L.) Beauv. - [8285.2, 2010, MCs].

2512. Setaria pumila (Poir.) Schult. - [8188.2, 2010, MCs].

2515. Setaria viridis (L.) Beauv. - [7793.1, 2012, MCs]. [7886.2, 2013, MCs]. [8188.2, 2010, MCs].

2527. Arum orientale M. Bieb. - Pátka: Páskom, utak mente [8776.2, 2016, KGK].

2541. Typha Iaxmannii Lepech. - Hortobágy: Akadémia-halastó [8492.1, 2016, KG] és Kónya, vasúti m.h. közelében útárokban [8393.3, 2016, KG]. Nagyiván: Labodás, útárok [8591.2, 2016, KG].

2551. Schoenoplectus tabernaemontani (C.C.Gmel.) Palla - Szentistván: Csincse-ér és Batúz-tanya között [8290.4, 2014, MCs].

2573. Eleocharis palustris (L.) Roem. et Schult. s. str. - [8269.3, 2016, HGy]. [7994.4, 2014, MCs].

2578. Cyperus flavescens L. - Ajka-Bakonygyepes: Széki-erdőtől keletre eső forráslápon [8871.3, 2003, MVA].

2593. Carex praecox Schreb. - [8289.4, 2014, MCs]. [8269.4, 2016, HGy]. [9073.3, 2007, MCs]. [7992.4, 8092.2, 2014, MCs]. [7993.3, 2014, MCs]. [7994.4, 2014, MCs].

2599. Carex spicata Huds. - Gyöngyösoroszi: Bárány-domb déli részén [8185.3, 2006, MCs]. Tornanádaska: Temető-dúlő, kaszált parlagon [7490.2, 2014, MCs].

2602. Carex otrubae Podp. - Kisújszállás: Nagy-erdő, erdőszélen [8790.3, 2006, MCs].

2608. Carex stenophylla Wahlenb. - [7491.3, 2014, MCs]. [8289.2, 8289.4, 2014, MCs]. [8192.3, 2014, MCs].

2610. Carex elata All. - Jánossomorja: Kerti-Bokor rétek [8269.3, 2016, HGy]. Lébény: Fűzfaszigetek, Urhanyi rétek, Polgári-Pintér Hany, Pintér-Hany [8269.2, 8269.4, 8270.1, 8270.3, 2016, HGy]. Újrónafő: Krisztina-berek [8269.2, 2016, HGy].

2622. Carex humilis Leyss. - Gyöngyöstarján: Gereg-hegy egyik kis D-i sziklacsúcsa [8184.4, 2010, MCs]. 
2625. Carex caryophyllea Latourr. - Gyöngyöspata: Gereg [8184.4, 2005, MCs]. Monok: Zsebrik [7792.4, 2005, MCs].

2626. Carex tomentosa L. - Szendrőlád: Csákány [7690.2, 2014, MCs]. Gyöngyösoroszi: Bárány-domb déli részén és Gyöngyöstarján: Hosszú-hegy [8185.3, 2006, MCs]. Gyöngyössolymos: Tarma-oldal [8185.4, 2007, MCs]. Gyöngyöstarján: Havas lába, cserestölgyesben, valamint Gereg-hegy és környéke, erdőssztyeppréten és tatárjuharoslösztölgyesben [8184.4, 2010, MCs].

2631. Carex pendula Huds. - Kelemér: Kis-Mohos-tó [7688.4, 2013, MCs].

2634. Carex sylvatica Huds. - Gömörszőlős: Egerdő, gyertyános-kocsányos tölgyesben [7688.2, 2013, MCs].

2635. Carex pilosa Scop. - Feldebrő: Cser, völgyalji, üde erdő [8187.3, 2007, MCs].

2636. Carex pallescens L. - Eger-Felnémet: Ostoros-völgy és Tó-lápa [8088.3, 2010, MCs]. Fony: Csepegő-forrás körüli gyepekben [7593.4, 2014, MCs]. Gyöngyös: Sár-hegy [8285.2, 2010, MCs]. Gyöngyöstarján: Havas lába, cseres-tölgyesben [8184.4, 2008, MCs]. Mikóháza: Nagy-Polyán, legelőn [7595.2, 2010, MCs].

2641. Carex vesicaria L. - Nagyiván: Nagy-fenék [8491.4, 2013, KG]. Nádudvar: Zádor-lapos [8592.1, 2016, KG].

2642. Carex melanostachya M.Bieb. ex Willd. - Mikóháza: Nagy-Polyán [7595.2, 2010, MCs].

2647. Carex michaelii Host - Aggtelek: Kardos-völgy, csarabosban [7589.3, 2013, MCs]. Gömörszőlős: Zánkó-hegy [7688.2, 2013, MCs].

2656. Carex distans L. - Szentistván: Salamon-major mellett a Tiszavalki-főcsatornánál [8290.4, 2014, MCs].

2676. Cephalanthera damasonium (Mill.) Druce - Kisújszállás: Nagy-erdő, E15-ös út melletti mezei juharos tölgyes szegélyében [8790.3, 2006, MCs]. Székesfehérvár: Csalai öreg szürkenyáras [8876.1, 2016, KGK] és Zágoni utcai tölgyes [8776.4, 2016, KGK].

2693. Dactylorhiza incarnata (L.) Soó - Lovasberény: Büdös-tó melletti patakvölgyi rét [8677.3, 2015, KGK]. Pátka: Rovákja-torkolat, Zámolyi-víztározó délkeleti partja [8776.2, 2016, KGK].

2700. Orchis morio L. - Székesfehérvár: Borszéki úti láprét [8876.1, 2017, KGK]. Pátka: Páskom, legeltetett udvar [8776.2, 2016, KGK] és a Zámolyi-víztározó zárógátja mentén [8776.2, 2017, KGK].

2701. Orchis coriophora L. - Székesfehérvár: Borszéki úti láprét [8876.1, 2016, KGK]. Pátka: Rovákja-torkolat, Zámolyi-víztározó délkeleti partja [8776.2, 2016, KGK].

2704. Orchis purpurea Huds. - Kincsesbánya: Gúttamásira vezető út mellett [8775.2, 2009, KGK]. Szendrőlád: Csákány [7690.2, 2014, MCs]. Székesfehérvár: Pénzverő-völgy [8776.4, 2014, KGK].

2705. Orchis militaris L. - Székesfehérvár: Borszéki úti láprét [8776.4, 2016, KGK], Császárvíz-völgy menti rét [8776.4, 2016, KGK], Zágoni utcai tölgyes [8876.1, 2016, KGK].

2708. Orchis elegans Heuff. - Nagyiván: Csíkos-ér, Zsombikos, Mérges [8591.2, 2015, KG]. Nádudvar: Zádor-lapos [8592.1, 2012, KG].

2709. Orchis palustris Jacq. - Lovasberény: Büdös-tó melletti patakvölgyi rét [8677.3, 2015, KGK]. Pátka: Pátkai-víztározó keleti gátja mellett [8776.2, 2016, KGK] és Sós-ér maradványa, a pátkai Vargahegytől nyugatra [8777.1, 2016, KGK].

\section{Köszönetnyilvánítás}

Molnár Csaba köszönetét fejezi ki sokirányú segítségükért Bartha Sándornak, Biró Mariannának, Farkas Józsefnek, Illyés Eszternek, Juhász Melindának, Kiss Balázsnak, Kovács Anikónak, Molnár Zsoltnak, Rédei Tamásnak, Türke Ildikó Juditnak, továbbá Kovács Gábor Molnár Attilának, valamint Kovács Gergely Károly Staudinger Istvánnak és Szili Istvánnak. 


\section{Irodalom}

Bartha D., Király G., Schmidt D., Tiborcz V., Barina Z., Csiky J., Jakab G., Lesku B., Schmotzer A., Vidéki R., VojTкó A. \& Zólyomi Sz. (szerk.) (2015): Magyarország edényes növényfajainak elterjedési atlasza. Nyugat-magyarországi Egyetem Kiadó, Sopron, 329 pp.

KIRÁLY G. (szerk.): Új Magyar Füvészkönyv. Magyarország hajtásos növényei. Határozókulcsok. Aggteleki Nemzeti Park Igazgatósága, Jósvafó.

Molnár Cs., Lengyel A., Molnár V. A., NAgy T., Csábi M. \& TAKÁCs A. (2016): Pótlások Magyarország edényes növényfajainak elterjedési atlaszához II. - Kitaibelia 21 (2): 227-252.

NikLfELD H. (1971): Bericht über die Kartierung der Flora Mitteleuropas. - Taxon 20 (4): 545-571.

Takács A., Nagy T., Sramkó G., Lovas-Kiss Á., SÜveges K., LuKács B. A., FeKETE R., LöKi V., Malatinszky Á., E. Vojtkó A., Koscsó J., Pfliegler W. P., Nótári K. \& Molnár V. A. (2016): Pótlások a Magyarország edényes növényfajainak elterjedési atlaszához I. - Kitaibelia 21 (1): 101-115.

Beérkezett: 2017. 05. 18. • Elfogadva: 2017. 05. 25. 